\title{
Treatment of electrolyte disorders in adult patients in the intensive care unit
}

\author{
Michael D. Kraft, Imad F. Btaiche, Gordon S. SACKS, AND Kenneth A. Kudsk
}

E lectrolytes are involved in many metabolic and homeostatic functions, including enzymatic and biochemical reactions, the maintenance of cell membrane structure and function, neurotransmission, nerve signal conduction, hormone function, muscle contraction, cardiovascular function, bone composition, and fluid and acid-base regulation. In addition to serum electrolyte concentrations, signs and symptoms of specific electrolyte disorders should be monitored in patients with electrolyte abnormalities. The severity of symptoms related to electrolyte disorders generally correlates with the severity of the disorder and the rate at which the disorder developed. Multiple mechanisms may be involved in electrolyte abnormalities in adult patients in the intensive care unit (ICU), including altered absorption and distribution; excessive or inadequate administration; alterations in hormonal, neuro-
Purpose. The treatment of electrolyte disorders in adult patients in the intensive care unit (ICU), including guidelines for correcting specific electrolyte disorders, is reviewed.

Summary. Electrolytes are involved in many metabolic and homeostatic functions. Electrolyte disorders are common in adult patients in the ICU and have been associated with increased morbidity and mortality, as has the improper treatment of electrolyte disorders. A limited number of prospective, randomized, controlled studies have been conducted evaluating the optimal treatment of electrolyte disorders. Recommendations for treatment of electrolyte disorders in adult patients in the ICU are provided based on these studies, as well as case reports, expert opinion, and clinical experience. The etiologies of and treatments for hyponatremia hypotonic and hypernatremia (hypovolemic, isovolemic, and hypervolemic), hypokalemia and hyperkalemia, hypophosphatemia and hyperphosphatemia, hypocalcemia and hypercalcemia, and hypomagnesemia and hypermagnesemia are discussed, and equations for deter- mining the proper dosages for adult patients in the ICU are provided. Treatment is often empirical, based on published literature, expert recommendations, and the patient's response to the initial treatment. Actual electrolyte correction requires individual adjustment based on the patient's clinical condition and response to therapy. Clinicians should be knowledgeable about electrolyte homeostasis and the underlying pathophysiology of electrolyte disorders in order to provide the optimal therapy to patients.

Conclusion. Treatment of electrolyte disorders is often empirical, based on published literature, expert opinion and recommendations, and patient's response to the initial treatment. Clinicians should be knowledgeable about electrolyte homeostasis and the underlying pathophysiology of electrolyte disorders to provide optimal therapy for patients.

Index terms: Calculations; Critical illness; Dosage; Electrolytes; Equations; Methodology; Mortality; Protocols; Water-electrolyte imbalance

Am J Health-Syst Pharm. 2005; 62:1663-82
MiCHAEL D. KRAFT, PHARM.D., is Clinical Assistant Professor, De-
partment of Clinical Sciences, College of Pharmacy, University of
Michigan (UM), Ann Arbor, and Clinical Pharmacist, Department of
Pharmacy Services, University of Michigan Health System (UMHS),
Ann Arbor. IMAD F. BTAICHE, PHARM.D., BCNSP, is Clinical Associ-
ate Professor, Department of Clinical Sciences, College of Pharmacy,
UM, and Clinical Pharmacist, Department of Pharmacy Services,
UMHS. GORDON S. SACKS, PHARM.D., BCNSP, is Clinical Associate
Professor, Pharmacy Practice Division, School of Pharmacy; and
KENNETH A. KUDSK, M.D., is Professor of Surgery, Department of
Surgery, University of Wisconsin-Madison.

Address correspondence to Dr. Kraft at the Department of Pharmacy Services, University of Michigan Health System, UH/B2 D301, Box 0008, 1500 East Medical Center Drive, Ann Arbor, MI 481090008 (mdkraft@umich.edu).

Copyright (c) 2005, American Society of Health-System Pharmacists, Inc. All rights reserved. 1079-2082/05/0802-1663\$06.00.

DOI 10.2146/ajhp040300 
logic, and homeostatic mechanisms; or altered excretion via gastrointestinal (GI) and renal losses, as well as changes in fluid status and fluid shifts. Excessive losses should be corrected by administering the appropriate replacement fluid (i.e., composition of the replacement fluid should match that of the fluid lost) in adequate amounts (e.g., $0.5-1 \mathrm{~mL}$ per $1 \mathrm{~mL}$ of output) and giving maintenance fluids. Clinicians should always consider the possibility of laboratory error, sampling error, or blood-sample hemolysis before initiating therapy, especially when the patient is asymptomatic and electrolytes were previously normal with little or no change in therapies or clinical condition. If an error is suspected, a repeat analysis should be obtained before treatment. Since the kidney is the major organ involved in fluid and electrolyte homeostasis, very close attention must be given to renal function in all patients before correcting any electrolyte disorder.

The pathophysiology, etiology, and clinical manifestations of specific electrolyte disorders have been thoroughly reviewed. ${ }^{1-47}$ This review focuses on the treatment of such disorders in adult patients in the ICU and is intended to provide clinicians with guidelines for correcting specific electrolyte disorders in these patients by applying estimations based on evidence in the literature and clinical experience. Actual electrolyte correction requires individual adjustment by evaluating the patient's clinical condition and response to therapy. The equations and recommendations provided are not meant to replace sound clinical judgment and knowledge of electrolyte homeostasis and the underlying pathophysiology of electrolyte disorders.

\section{Dosing guidelines}

There are limited data and conflicting opinions and recommendations on the dosing of electrolytes in adult patients in the ICU. In addition, there are no definitive recommendations for the optimal dosing weight for adult patients, particularly the obese. Clinicians frequently "adjust” body weight (e.g., using body mass index [BMI] or percent above ideal body weight [IBW]) in patients who are obese; however, there are no data identifying the optimal way to estimate this adjusted weight. Furthermore, there is considerable debate as to what degree of obesity the clinician should consider to use an adjusted body weight or how to appropriately adjust body weight to optimize dosing and minimize the risk for overdose and associated adverse effects. Total body water in men is slightly higher than that in women, and it is estimated that adipose tissue is composed of approximately 10$30 \%$ water. ${ }^{48-52}$ Therefore, we suggest using an adjusted body weight (AdjBW) in obese adult patients ${ }^{48-52}$ (i.e., actual weight $>130 \%$ of IBW or BMI $\geq 30 \mathrm{~kg} / \mathrm{m}^{2}$ ) when weight-based dosing is required using the following calculations:

AdjBW $($ men $)=([$ weight in $\mathrm{kg}-\mathrm{IBW}$ in $\mathrm{kg}] \times 0.3)+$ IBW

AdjBW $($ women $)=([$ weight in $\mathrm{kg}-$ IBW in $\mathrm{kg}] \times 0.25)+$ IBW

\section{Sodium}

Sodium is the most abundant extracellular cation and has a normal serum concentration of 135-145 meq/L. Normal homeostatic mechanisms keep the serum sodium concentration and serum osmolality (275-290 mosmole/kg water) within narrow therapeutic ranges. Osmotic pressure and osmolality determine the distribution of water between various body compartments, with sodium being the major osmotically active substance in the extracellular fluid. Water will flow from the compartment with lower osmolality to the compartment of higher osmolality until osmotic equilibrium is achieved. Serum osmolality can be measured directly or calculated using the following equation:

Serum osmolality (mosmole/kg in water $)=(2 \times$ serum sodium conc. in $\mathrm{meq} / \mathrm{L})+($ serum urea conc. in $\mathrm{mg} / \mathrm{dL} / 2.8)+($ serum glucose conc. in $\mathrm{mg} / \mathrm{dL} / 18$ )

Changes in serum sodium concentration usually reflect changes in water balance; however, total body sodium concentration may be increased, decreased, or normal. Therefore, volume status must also be assessed in patients with hyponatremia or hypernatremia before initiating treatment. Rose and Post $^{1}$ have written an excellent review and discussion of the concepts of sodium and water balance and plasma osmolality.

Sodium imbalances are common in ICU patients, yet often poorly understood. Caution must be exercised to avoid inappropriate correction of the sodium imbalance, which could result in further complications, morbidity, and death. ${ }^{1,2,53-66}$

Hyponatremia. Hyponatremia (serum sodium concentration of $<135 \mathrm{meq} / \mathrm{L}$ ) may reflect increased, decreased, or normal total body sodium concentrations and necessitates assessment of serum osmolality. As hypoosmolar (hypotonic) hyponatremia can develop in the presence of hypovolemia, isovolemia, or hypervolemia, the patient's fluid volume must also be assessed. The potential etiologies of hyponatremia are numerous, depending on the patient's serum osmolality and fluid volume (Figure 1). $., 3,6,8,9$

The signs and symptoms of hyponatremia are often nonspecific, and most are related to the change in serum osmolality and consequent fluid shifts in the central nervous system (CNS). These signs and symptoms can include headache, lethargy, disorientation, restlessness, nausea, vomiting, muscle cramps or weakness, depressed reflexes, seizures, 
Figure 1. Classification and common etiologies of hyponatremia. $.^{1,3,6,8,9} \mathrm{NSAIDs}=$ nonsteroidal antiinflammatory drugs.

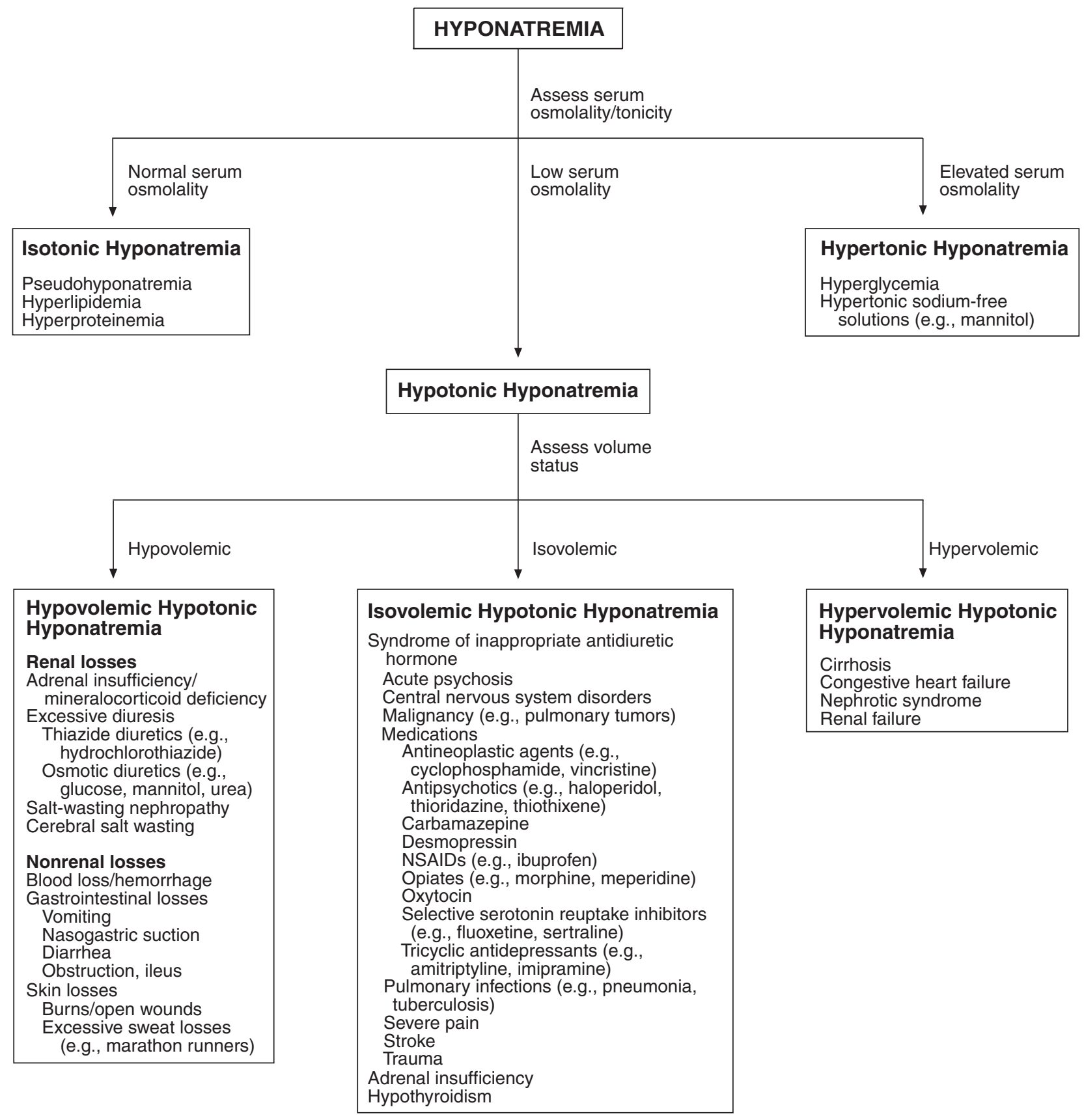

coma, and death. ${ }^{7-9}$ In addition, evidence of hypovolemia or hypervolemia may be present, depending on the etiology of the hyponatremia and the patient's volume status. The severity of symptoms is related to the rate of development and severity of hyponatremia, with more severe symptoms developing in patients with acute reductions in serum sodium concentrations over 12 hours or less. ${ }^{9,67}$ Documented hyponatremia (serum sodium concentration of $<130 \mathrm{meq} / \mathrm{L}$ ) is associated with up to a 60 -fold increase in mortality, and mortality rates are significantly higher in patients whose serum sodium concentration drops below $120 \mathrm{meq} / \mathrm{L}^{68}$
Morbidity and mortality may be due to hyponatremia itself, the underlying disease state, or the inappropriate treatment of hyponatremia. Proper treatment depends on prompt and appropriate identification, diagnosis, and classification and is based on the patient's serum osmolality and fluid volume. ${ }^{3,6-11,13,69-93}$ 
Symptomatic hyponatremia. Severe symptomatic hyponatremia (e.g., altered mental status, seizures) requires prompt correction with free-water restriction and i.v. administration of hypertonic saline (e.g., $3 \%$ sodium chloride injection $=512$ meq sodium/L) at a rate of $15-80$ $\mathrm{mL} / \mathrm{hr}^{9,11,69}$ or up to $1-2 \mathrm{~mL} / \mathrm{kg} / \mathrm{hr}$ for two to three hours, ${ }^{6,8,11}$ with the possible addition of a loop diuretic (e.g., furosemide) in nonhypovolemic patients. ${ }^{11,70}$ Reversible causes of hyponatremia (e.g., excessive i.v. administration of hypotonic fluids, such as $5 \%$ dextrose injection) should first be identified and corrected with the restriction of hypotonic fluids.

The approximate sodium deficit should be calculated to estimate replacement needs using the following equation:

Sodium deficit $($ meq $)=$ TBW $\times$ $(140$ - measured serum sodium conc.),

where

$\mathrm{TBW}(\mathrm{men})=0.6 \mathrm{~L} / \mathrm{kg} \times$ weight in $\mathrm{kg}$ and TBW $($ women $)=0.5 \mathrm{~L} / \mathrm{kg} \times$ weight in $\mathrm{kg}$

The estimated percentage of body water for normal men is $60 \%(0.6)$ and the estimated percent body water for normal women is $50 \%(0.5)$. These percentages are often higher in ICU patients. We suggest using the AdjBW to calculate the sodium deficit of patients who are significantly obese.

Serum sodium concentrations should be corrected at a rate of 1-2 $\mathrm{meq} / \mathrm{L} / \mathrm{hr}$ for patients with symptomatic hyponatremia or severe acute hyponatremia (e.g., change in serum sodium concentration of $>0.5$ $\mathrm{meq} / \mathrm{L} / \mathrm{hr}$ or onset in less than 48 hours) $)^{6,10,55,56,58-60,71}$ and no faster than $0.5 \mathrm{meq} / \mathrm{L} / \mathrm{hr}$ when hyponatremia is chronic (i.e., develops over more than two or three days) or when the time over which the hyponatremia developed is unknown. ${ }^{54,55,58,61,63}$
The maximum recommended increase in serum sodium concentration is $8-12 \mathrm{meq} / \mathrm{L}$ per 24 hours, $9,54,55,59,61-65$ with complete correction over 48-96 hours. Fifty percent of the estimated sodium deficit is usually administered over the first 24 hours and the remainder over the next 24-72 hours. A reasonable short-term treatment goal is to correct the serum sodium to $120-130$ $\mathrm{meq} / \mathrm{L}^{55,56,59,61,63,65,72,73}$ or lower in patients whose serum sodium concentration is $\leq 105 \mathrm{meq} / \mathrm{L} . .^{55,63,65,72,73} \mathrm{Se}-$ rum sodium concentration should not be corrected initially to more than $135 \mathrm{meq} / \mathrm{L}^{56}$ and should not exceed the upper limit of normal (145 $\mathrm{meq} / \mathrm{L}$ ) at any time during treatment. Serum sodium levels should be monitored frequently (e.g., every $2-4$ hours) until the patient is asymptomatic, then every 4-8 hours until the serum sodium is within the normal range. Overly rapid correction of serum sodium levels can induce neurologic complications, including central pontine myelinolysis, ${ }^{53-59,61-64}$ which manifests clinically as a gradual onset of neurologic alterations occurring within one to six days of rapid correction. Findings may include pseudobulbar palsy, quadriparesis, seizures, and movement disorders.

Alternatively, one can estimate the anticipated change in serum sodium levels after i.v. infusion of $1 \mathrm{~L}$ of $3 \%$ sodium chloride injection using the following equation ${ }^{69}$ :

Change in serum sodium conc. $=$ (512 meq/L - serum sodium conc.)/TBW +1

and after i.v. infusion of $1 \mathrm{~L}$ of $0.9 \%$ sodium chloride injection with the following equation ${ }^{69}$ :

Change in serum sodium conc. $=$ $(154 \mathrm{meq} / \mathrm{L}$ - serum sodium (conc.)/TBW +1

With this calculation, initiation of $3 \%$ sodium chloride injection at $15-$
$50 \mathrm{~mL} / \mathrm{hr}$ may be an appropriate starting point (depending on the severity of hyponatremia). Adjustments should be based on the patient's response and calculated with the above equations.

Hypovolemic hypotonic hyponatremia. In patients with hypovolemic hypotonic hyponatremia, the approximate sodium deficit should be calculated to estimate replacement needs and corrected with $0.9 \%$ sodium chloride injection or lactated Ringer's solution according to guidelines for rate of correction and monitoring discussed previously.

Isovolemic hypotonic hyponatremia. Isovolemic hypotonic hyponatremia is treated with water restriction. Mild diuresis with a loop diuretic (e.g., i.v. furosemide 20-40 mg every 6-12 hours) may also be helpful. Syndrome of inappropriate antidiuretic hormone (SIADH) is the most common cause of isovolemic hypotonic hyponatremia. SIADH is characterized by an inappropriate response of antidiuretic hormone $(\mathrm{ADH})$ to any volume or osmotic stimuli that normally affect ADH secretion. There may be increased $\mathrm{ADH}$ release or increased kidney response to $\mathrm{ADH}$. Patients are hyponatremic in the setting of serum hypotonicity $(<270$ mosmole/L) and do not have evidence of edema or pituitary, thyroid, adrenal, cardiac, renal, or hepatic dysfunction. ${ }^{3,6,8} \mathrm{~Pa}$ tients have impaired free-water excretion, with normal excretion of sodium. The urine is inappropriately concentrated ( $>100$ mosmole/kg) with an increase in urine sodium concentration of greater than 20-30 meq/L., 3,68 The continued intake of water (or hypotonic fluids) will ultimately lead to the development of hyponatremia. Numerous conditions and medications may induce SIADH (Figure 1). In the case of drug-induced SIADH, the suspected agent should be discontinued, if possible. The primary acute therapy for SIADH is correction of the underly- 
ing disorder and water restriction $\left(<1000\right.$ to $1500 \mathrm{~mL}$ daily). ${ }^{3,6,74} \mathrm{~Pa}-$ tients with severe symptomatic SIADH may require more aggressive therapy with i.v. furosemide $1 \mathrm{mg} / \mathrm{kg}$ as needed to maintain desired negative fluid balance and replacement of urinary sodium losses with hypertonic saline (3\% sodium chloride injection). ${ }^{3,6,70}$ Other drug therapies for SIADH include oral or i.v. furosemide (30-80 mg daily) with oral sodium chloride supplementation ${ }^{75-78}$ and oral urea crystals (30-60 g daily). ${ }^{79-81}$ However, the use of oral urea has been limited in clinical practice. $^{74,78}$ Demeclocycline hydrochloride $600-1200 \mathrm{mg}$ orally daily can be used to treat chronic SIADH, ${ }^{82-85}$ but it is not as effective for treating acute SIADH because of its delayed onset of action. ${ }^{78,84}$ Demeclocycline should be used with caution because it may have potentially negative effects on renal function, ${ }^{83,84,86}$ especially in patients with underlying hepatic dysfunction ${ }^{87,88}$ or congestive heart failure. ${ }^{89,90}$ Phenytoin sodium 200-300 mg orally daily may be an alternative therapy for chronic SIADH, but not for acute management. ${ }^{91}$ Lithium carbonate $600-1200 \mathrm{mg}$ orally daily has been used as a last line of therapy for SIADH $^{74,78,92}$; however, its use may be limited by its toxicity ${ }^{74,78,84}$ and lack of efficacy. ${ }^{84}$

Hypervolemic hypotonic hyponatremia. Hypervolemic hypotonic hyponatremia often occurs in critically ill patients, especially those with cardiac, renal, or hepatic insufficiency. It also occurs in postoperative patients due to the i.v. administration of large volumes of resuscitation fluids. Patients with renal failure who develop hyponatremia will usually have a decreased effective serum osmolality, but the measured serum osmolality may be elevated due to uremia. However, because urea distributes freely across membranes and is considered an ineffective osmole, it does not contribute to the effective osmolality. Therefore, hyponatremia in patients with renal failure is usually classified as hypotonic because the effective serum osmolality is generally reduced.

Treatment includes optimizing treatment of the underlying cause, in addition to sodium and fluid restriction (e.g., 1000-1500 mL daily) and diuresis with a loop diuretic (e.g., furosemide).

Isotonic hyponatremia and hypertonic hyponatremia. Therapy for isotonic hyponatremia and hypertonic hyponatremia should be aimed at identifying and correcting the underlying cause. Hypertonic hyponatremia may result from hyperglycemia or administration of hypertonic sodium-free solutions. Hyperglycemia causes a shift of water out of cells into the extracellular space, resulting in dilution of serum sodium. For every $100-\mathrm{mg} / \mathrm{dL}$ increase in serum glucose concentration above $100 \mathrm{mg} / \mathrm{dL}$, the serum sodium concentration would be expected to decrease by approximately $1.6 \mathrm{meq} / \mathrm{L} .{ }^{93}$ Therefore, the corrected serum sodium concentration should be calculated using the following equation before attempting the correction:

Corrected serum sodium conc. $=$
serum sodium conc. $+1.6([$ serum
glucose conc. -100$] / 100)$

Infusion of any sodium-free isotonic or hypertonic solutions (e.g., mannitol) should be stopped if clinically appropriate. Hyperglycemia should be controlled with insulin therapy (e.g., sliding-scale regular insulin or continuous i.v. infusion) and by avoiding excessive carbohydrate loads. Serum sodium levels should be monitored as previously described.

Pseudohyponatremia. Pseudohyponatremia occurs when there is an increase in the nonaqueous portion of the serum, such as with hyperlipidemia and hyperproteinemia. This is not a true hyponatremia, since the sodium concentration in the aqueous portion of the serum remains normal. Pseudohyponatremia has been historically related to the older method for measuring serum sodium levels using flame-emission spectrophotometry. This method has largely been replaced with a more specific technique that uses sodiumselective electrodes to measure serum sodium. However, this new technique may not completely eliminate the problem, and serum osmolality should be measured in patients with hyponatremia.

Hypernatremia. Hypernatremia (serum sodium concentration of $>145 \mathrm{meq} / \mathrm{L}$ ) reflects a water deficit relative to total body sodium levels and is associated with serum hypertonicity. Total body sodium may be increased, decreased, or normal, and assessment of the patient's volume status is required. There are several potential etiologies of hypernatremia, depending on the alteration in the patient's volume status (Table 1). ${ }^{3,6,8,14}$ Generally, hypernatremia develops when the thirst mechanism is not functioning normally or if access to free water is limited or controlled. ${ }^{3,70}$ The latter occurs in acutely ill ICU patients when fluid intake is controlled or restricted.

Table 1.

\begin{tabular}{lc}
\multicolumn{2}{c}{ Classification and Common Etiologies of Hypernatremia $3,6,8,14$} \\
\hline Classification & \multicolumn{1}{c}{ Etiology } \\
\hline Hypovolemic & $\begin{array}{c}\text { Loss of hypotonic fluids (vomiting, diarrhea, nasogastric } \\
\text { suctioning, osmotic diuresis, burns and open wounds, sweat, } \\
\text { lungs) } \\
\text { Diabetes insipidus (central diabetes, nephrogenic diabetes } \\
\text { insipidus) } \\
\text { Hypertonic saline solutions, sodium bicarbonate solutions, } \\
\text { mineralocorticoid excess (hyperaldosteronism) }\end{array}$ \\
\hline
\end{tabular}


Similar to hyponatremia, the signs and symptoms of hypernatremia can be nonspecific, and most are related to changes in serum osmolality in the CNS. Clinical manifestations of hypernatremia in adult patients can include lethargy, irritability, restlessness, thirst, muscle irritability and spasticity, hyperreflexia, seizures, coma, and death. ${ }^{7,8,14}$ Evidence of hypovolemia or hypervolemia may be present. Severity of symptoms may also correlate with severity and the rate of development of hypernatremia. ${ }^{7,14}$

Hypernatremia is associated with increased morbidity and mortality. ${ }^{6,94-96}$ The overall mortality rate in adult patients with hypernatremia is approximately $40-70 \%,{ }^{94-96}$ although the mortality rate directly attributed to hypernatremia itself is likely lower. ${ }^{95}$ Adults with a serum sodium concentration of $>160 \mathrm{meq} / \mathrm{L}$ have a mortality rate of $>75 \% .{ }^{694}$ Mortality associated with chronic hypernatremia is lower than with acute hypernatremia. ${ }^{6,94,96}$ Morbidity and mortality associated with hypernatremia are often due to the underlying disease process or inappropriate treatment of the disorder. $^{94,95}$ Therefore, prompt assessment, diagnosis, and proper therapy of hypernatremia are essential.

Proper treatment depends on the characterization of hypernatremia (hypovolemic, isovolemic, or hypervolemic) and its magnitude, length of time over which it developed, and the severity of symptoms. All reversible causes should be identified and corrected. Administration of sodium (e.g., hypertonic saline or sodium bicarbonate) should be discontinued or reduced if clinically appropriate, the sodium concentration of i.v. fluids should be lowered (e.g., $0.225 \%$ sodium chloride injection or $5 \%$ dextrose injection), and medication solvents should be changed to $5 \%$ dextrose injection, if compatible. If hypernatremia developed rapidly (i.e., over a period of hours), correction is usually well tolerated because brain cells have not yet fully adapted to the imbalance. ${ }^{2}$ However, the mortality rate increases with more rapid correction of hypernatremia. ${ }^{94}$ Therefore, in the case of acute hypernatremia, the serum sodium concentration should be corrected no faster than 1-2 meq/L/hr to avoid cerebral edema. ${ }^{8,14,97}$ Extreme caution is warranted in the case of chronic hypernatremia or if hypernatremia developed over an unknown length of time, because rapid correction can result in brain edema, swelling, herniation, and death. ${ }^{2}$ In these cases, the serum sodium concentration should be corrected at a maximum rate of $0.5 \mathrm{meq} / \mathrm{L} / \mathrm{hr}^{.14,98}$

The anticipated change in serum sodium levels after i.v. infusion of $1 \mathrm{~L}$ of $5 \%$ dextrose injection can be estimated using the following equation ${ }^{69}$ :

Change in serum sodium conc. $=(0$ meq/L - serum sodium conc.)/ $(\mathrm{TBW}+1)$

and after i.v. infusion of $1 \mathrm{~L}$ of $0.225 \%$ sodium chloride injection with the following equation ${ }^{69}$ :

Change in serum sodium conc. = (38.5 meq/L - serum sodium conc. $) /(\mathrm{TBW}+1)$

and after i.v. infusion with $1 \mathrm{~L}$ of $0.45 \%$ sodium chloride injection with the following equation:

Change in serum sodium conc. $=(77$ meq/L - serum sodium conc.)/ $(\mathrm{TBW}+1)$

and after i.v. infusion with $1 \mathrm{~L}$ of $0.9 \%$ sodium chloride injection with the following equation ${ }^{69}$ :

Change in serum sodium conc. $=$ (154 meq/L - serum sodium conc. $) /(\mathrm{TBW}+1)$

Alternatively, the relative water deficit associated with hypernatre- mia can be estimated using the following equation:

Water deficit $($ in liters $)=$ TBW $\times$ ([serum sodium conc./140] - 1)

Half of the water deficit should be replaced over the first 24 hours, and the remainder replaced over the following 24-72 hours, with the total correction taking place over 48-96 hours. ${ }^{8,14,95,97}$ Serum sodium concentration should be decreased by a maximum of $10-12 \mathrm{meq} / \mathrm{L}$ per 24 hours. ${ }^{14,98}$ When the patient is hypovolemic or hypotensive, isotonic $0.9 \%$ sodium chloride injection or lactated Ringer's solution should be used to help correct the hemodynamic instability. Otherwise, $5 \%$ dextrose injection or a hypotonic saline solution $(0.225 \%$ or $0.45 \%$ sodium chloride injection) can be used.

Patients with symptomatic hypernatremia (e.g.) altered mental status, seizures, coma) should have their sodium levels monitored every 2-4 hours. Once symptoms resolve, serum sodium should be monitored frequently (i.e., every 4-8 hours) until normal. A goal serum sodium concentration of $145 \mathrm{meq} / \mathrm{L}$ has been suggested. ${ }^{14}$

Hypovolemic hypernatremia. The water deficit associated with this condition should be calculated. After correcting the initial hypovolemia with $0.9 \%$ sodium chloride injection or lactated Ringer's solution in hemodynamically unstable patients, the water deficit should be corrected with a hypotonic solution. The appropriate type and amount of maintenance fluid should be provided, along with treatment of the deficit to prevent further dehydration.

Isovolemic hypernatremia. Isovolemic hypernatremia can result from a relative water deficit (i.e., free-water or hypotonic sodium losses) or relative sodium excess (e.g., isotonic sodium administration [ $0.9 \%$ sodium chloride injection] for hypotonic losses, such as those through the skin). The relative water 
deficit should be calculated to guide treatment, and sodium restriction is also warranted. Isovolemic hypernatremia is typically seen in patients with diabetes insipidus (DI). DI results in excretion of a large volume of hypotonic urine (e.g., 3-15 L daily) and polydipsia. ${ }^{3,15}$ The differentiation should be made between central DI (CDI) and nephrogenic DI (NDI). CDI is a result of impaired synthesis or the release of $\mathrm{ADH}$, and NDI results from a lack of kidney responsiveness to ADH. Urinary response (volume and osmolality) to administration of exogenous $\mathrm{ADH}$ (e.g., desmopressin acetate $1 \mu$ g s.c.) can differentiate between CDI and NDI. ${ }^{15}$ Common etiologies of CDI include trauma, neurosurgery, tumors, head trauma, infection, or cerebrovascular diseases (e.g., thrombosis, aneurysm) ${ }^{6,8,15} \mathrm{NDI}$ can be acquired or, more rarely, congenital. Common causes of acquired NDI include hypokalemia, hypercalcemia, polycystic kidney disease, advanced renal diseases, and medications, such as lithium (most commonly), ${ }^{15,99} \mathrm{de}-$ meclocycline, foscarnet, antipsychotics (e.g., clozapine), gentamicin, amphotericin $\mathrm{B}$, and cimetidine. ${ }^{6,8,15,16,100}$

I.V. 5\% dextrose injection should be administered to balance urine losses. Treatment of CDI may include the administration of an $\mathrm{ADH}$ analog (e.g., desmopressin acetate $10-20 \mu \mathrm{g}$ intranasally twice daily or $1-2 \mu$ g subcutaneously twice daily). ${ }^{15}$ Treatment of NDI includes removing the causative agent. A thiazide diuretic or indomethacin may be beneficial but should be used cautiously because of potentially negative renal effects. ${ }^{16}$ Lithium-induced NDI may be treated successfully with oral hydrochlorothiazide $50 \mathrm{mg}$ twice daily, ${ }^{101}$ oral indomethacin $50 \mathrm{mg}$ three times daily, ${ }^{102}$ or oral amiloride hydrochloride 5-10 mg twice daily. ${ }^{103}$

Hypervolemic hypernatremia. Hypervolemic hypernatremia is usually a result of the administration of hypertonic saline solutions, sodium bicarbonate solutions, or large volumes of isotonic saline $(0.9 \%$ sodium chloride) in the ICU to maintain circulation and blood pressure. Patients may also have ongoing losses of hypotonic body fluids (e.g., GI losses). It is best treated with the removal of sodium products, sodium restriction, and the use of diuretics (loop or thiazide) to restore normonatremia and euvolemia. Hypotonic saline (e.g., $0.225 \%$ sodium chloride) or $5 \%$ dextrose injection can also be administered with diuretics during correction of hypernatremia to decrease total body sodium and volume while providing maintenance fluid and preventing further abnormalities.

\section{Potassium}

Potassium is the second most abundant cation in the body. Approximately $98 \%$ of total body potassium is found in the intracellular space, with approximately $2 \%$ in the extracellular space. ${ }^{17,23}$ The normal serum potassium concentration is $3.5-5.0 \mathrm{meq} / \mathrm{L}$. Potassium has many physiological functions, including cellular metabolism, glycogen and protein synthesis, and regulation of the electrical action potential across cell membranes, especially in the myocardium. ${ }^{18,20}$

The rate-limiting step for potassium entry into the cells is the sodiumpotassium-adenosine triphosphatase pump that maintains a higher intracellular potassium level. Several factors affect the activity of this pump, including insulin, glucagon, cathecholamines, aldosterone, acid-base status, plasma osmolality, and intracellular potassium levels. Critically ill patients in the ICU often have abnormalities in one or more of these mediators or conditions. Under normal physiological conditions, $80 \%$ of potassium is excreted through the kidneys, with at least $90 \%$ actively reabsorbed along the kidney tubule. ${ }^{20}$ About $15 \%$ of potassium is excreted in feces and $5 \%$ in sweat. ${ }^{19,20}$
Hypokalemia. Hypokalemia is defined as a serum potassium concentration below $3.5 \mathrm{meq} / \mathrm{L}$ and considered severe if below $2.5 \mathrm{meq} / \mathrm{L}$ or if a patient is symptomatic. Because hypokalemia results in membrane hyperpolarization and impaired muscular contraction, its signs and symptoms generally involve changes in muscle and cardiovascular function. Patients with mild hypokalemia (e.g., serum potassium approximately 3-3.4 meq/L) may be asymptomatic. Signs and symptoms of hypokalemia include nausea, vomiting, weakness, constipation, paralysis, respiratory compromise, and rhabdomyolysis. ${ }^{18-22}$ The most severe and concerning adverse effects related to hypokalemia are electrocardiogram (ECG) changes, cardiac arrhythmias, and sudden death, especially in patients with hypertension, myocardial ischemia, or heart failure. ECG changes can include ST-segment depression, T-wave flattening, T-wave inversion, and the presence of $U$ waves. ${ }^{18-22}$

Hypokalemia can develop in ICU patients as a result of intracellular shifts of potassium, increased losses of potassium, or, less commonly, decreased ingestion or administration of potassium. Serum potassium levels do not correlate well with intracellular potassium levels ${ }^{104}$ and may not correlate with total body potassium. Therefore, hypokalemia may not imply a depletion of body potassium stores. Potassium supplementation and dosing are largely empirical and guided by serum potassium levels. It has been estimated that for every 0.3$\mathrm{meq} / \mathrm{L}$ decrease in serum potassium concentration, the total body potassium deficit is approximately 100 meq. ${ }^{21}$ Critically ill patients may have underlying conditions or receive medications that can cause hypokalemia. Metabolic alkalosis causes an intracellular shift of potassium; however, the total body potassium level will not change. Correction of the underlying metabolic alkalosis should result in redistribution of po- 
tassium into the extracellular space and correction of hypokalemia. Other common causes of hypokalemia due to intracellular shifts of potassium include $\beta$-adrenergic agonists (e.g., albuterol), insulin, theophylline, and caffeine. ${ }^{21,22}$ Common causes of hypokalemia due to potassium losses include potassium-wasting diuretics (loop and thiazide), sodium polystyrene sulfonate, corticosteroids (especially mineralocorticoids such as fludrocortisone), aminoglycosides, amphotericin $\mathrm{B}$, magnesium depletion, renal replacement therapies (e.g., hemodialysis, continuous renal replacement therapy [CRRT]), and GI losses (e.g., diarrhea, nasogastric suctioning)..$^{21,22}$

Goals of therapy for hypokalemia include avoidance or resolution of symptoms, returning the serum potassium concentration to the normal range (i.e., 3.5-5 meq/L), and avoiding hyperkalemia. Hypokalemia is treated by administering oral or i.v. potassium supplements. I.V. potassium supplementation (as chloride, acetate, or phosphate salts) is reserved for the treatment of severe hypokalemia, symptomatic hypokalemia, or when the GI tract cannot be used, and ICU patients may often have one or more of these conditions. Oral potassium supplements are available as chloride, bicarbonate, citrate, gluconate, and phosphate salts. The most commonly used oral or i.v. supplement is potassium chloride. Potassium acetate and bicarbonate can be used when the correction of acidemia is also desired. Potassium phosphate is used to cor-

Table 2.

\section{Empirical Treatment of Hypokalemia ${ }^{105-107}$}

\begin{tabular}{lcc}
\hline \multicolumn{1}{c}{ Severity } & $\begin{array}{c}\text { Serum Potassium } \\
\text { Concentration }(\mathrm{meq} / \mathrm{L})\end{array}$ & $\begin{array}{c}\text { I.V. Potassium } \\
\text { Replacement Dose }(\mathrm{meq})^{\mathrm{a}}\end{array}$ \\
\hline Mild to moderate & $2.5-3.4$ & $20-40$ \\
Severe & $<2.5$ & $40-80$ \\
\hline an patients with normal renal function; patients with renal insufficiency should receive $\leq 50 \%$ of the initial \\
empirical dose. Rate of infusion $=10-20$ meq potassium per hour; maximum infusion rate $=40$ meq potassium \\
per hour. Continuous cardiac monitoring and infusion via a central venous catheter are recommended for \\
infusion rates $>10$ meq potassium per hour. Maximum potassium $=80$ meq $/ L$ via a peripheral vein; up to 120 \\
meq/L via a central vein (admixed in $0.9 \%$ or $0.45 \%$ sodium chloride injection).
\end{tabular}

rect coexisting hypokalemia and hypophosphatemia.

We recommend an initial i.v. potassium dose of 20-40 meq for an ICU patient with mild to moderate hypokalemia (serum potassium concentration $=2.5-3.4 \mathrm{meq} / \mathrm{L})($ Table 2). ${ }^{105-107}$ Patients with symptomatic or severe hypokalemia (serum potassium concentration of $<2.5 \mathrm{meq} / \mathrm{L}$ ) require more aggressive therapy with initial i.v. potassium doses of up to 40-80 meq. Patients with impaired renal function should receive no more than $50 \%$ of the recommended initial potassium dose. Multiple doses of potassium can be repeated to normalize serum potassium concentrations if necessary; however, serum potassium levels should be checked after a total dose of 60-80 meq before further potassium is administered (within one to four hours after dose administration). Potassium should never be administered as a rapid infusion because of the risk of serious or fatal consequences. Intermittent potassium dosing can be safely achieved at potassium infusion rates of $10-20 \mathrm{meq} / \mathrm{hr}$. If an infusion rate exceeding $10 \mathrm{meq} / \mathrm{hr}$ is needed, continuous cardiac monitoring is recommended to detect any signs of hyperkalemia, and infusion via a central venous catheter is recommended to minimize infusionrelated burning and phlebitis. Potassium infusion rates exceeding 20 $\mathrm{meq} / \mathrm{hr}$ are rarely needed. In critical situations, infusion rates as high as $40 \mathrm{meq} / \mathrm{hr}$ have been used but should be reserved for emergent cases or symptomatic patients. ${ }^{107}$ Total daily 
may require i.v. therapy with higher doses. An alternative therapy to potassium supplementation in correcting or preventing hypokalemia is the use of potassium-sparing diuretics (e.g., spironolactone, triamterene, amiloride), which are especially useful in patients receiving drugs known to deplete potassium. ${ }^{20}$ However, in the acute setting, these agents may not be as effective as other agents (e.g., furosemide) in adult ICU patients when large volumes of excess fluid must be removed and excreted. In addition, the longer time to onset of these medications may be a limitation in treating acute hypokalemia.

Magnesium is important in the regulation of intracellular potassium. ${ }^{104}$ Hypomagnesemia may result in refractory hypokalemia, likely due to accelerated renal potassium loss or impairment of sodium-potassium pump activity. ${ }^{113}$ When hypokalemia and hypomagnesemia coexist, magnesium deficiency should be corrected to facilitate the correction of hypokalemia. ${ }^{114}$

Serum potassium levels should be monitored frequently (every 1-6 hours) in patients with severe hypokalemia if symptoms are present or if aggressive i.v. treatment is ongoing. Monitoring of serum potassium after i.v. repletion in ICU patients with mild to moderate hypokalemia (within 2-8 hours) may be appropriate, in addition to routine monitoring (e.g., every $24-48$ hours). The response to oral potassium repletion is generally delayed compared to i.v. repletion, and routine monitoring may be appropriate if hypokalemia is not severe and the patient is asymptomatic.

Hyperkalemia. Hyperkalemia (serum potassium concentration of $>5.0 \mathrm{meq} / \mathrm{L}$ ) can become life threatening when the serum potassium concentration exceeds $6.5 \mathrm{meq} / \mathrm{L}$. Clinical manifestations of hyperkalemia are related to changes in neuromuscular and cardiac function. Patients are often asymptomatic until the serum potassium concentration exceeds $5.5 \mathrm{meq} / \mathrm{L}$. Signs and symptoms of hyperkalemia include muscle twitching, cramping, weakness, ascending paralysis, ECG changes (e.g., tall peaked T-waves, prolonged PR-interval, widened QRS complex, shortened QT-interval) and arrhythmias (e.g., bradyarrhythmias, ventricular fibrillation, asystole). ${ }^{18-20,23}$

Similar to hypokalemia, true hyperkalemia can develop due to extracellular shifts of potassium, increased potassium ingestion, or impaired potassium elimination. Pseudohyperkalemia can be an artifact of hemolysis from a traumatic blood draw or when the blood sample is contaminated with infused potassium. As such, when a serum potassium level is inappropriately elevated for the clinical situation, the blood test must be repeated to confirm the diagnosis and avoid unnecessary or inappropriate treatment of hyperkalemia.

Hyperkalemia is most commonly seen in the setting of renal insufficiency, and acute renal failure is frequently seen in ICU patients. Potassium-sparing diuretics, angiotensin-converting-enzyme inhibitors, nonsteroidal antiinflammatory drugs, and hypoaldosteronism can impair potassium excretion and cause hyperkalemia. ${ }^{23}$ Metabolic acidosis results in an extracellular shift of potassium, without changes in total body potassium. Correction of the underlying metabolic acidosis redistributes potassium into the intracellular space and corrects the hyperkalemia. Other causes of extracellular shifts of potassium include succinylcholine, $\beta$-adrenergic blockers, digoxin overdose, and muscular injury (e.g., trauma, rhabdomyolysis). ${ }^{23}$

The goals of the hyperkalemia therapy are to antagonize the cardiac effects of potassium, reverse symptoms (if present), and return serum potassium to normal while avoiding overcorrection. All sources of exogenous potassium should be discontinued, and potassium-sparing diuretics and other medications that can cause hyperkalemia should be stopped, or the dosages decreased, if feasible. Table 3 lists therapies for the treatment of hyperkalemia. ${ }^{19,20,23}$ I.V. calcium (e.g., calcium gluconate) should be given to symptomatic patients or those with ECG changes, with the calcium dose repeated as needed based on the ECG changes. However, this is a temporary treatment to antagonize the effects of potassium and will not remove potassium from the body.

In patients without symptoms, rapid correction of hyperkalemia can be achieved by promoting intracellular distribution with insulin and dextrose, sodium bicarbonate, or albuterol. Sodium bicarbonate should be used with caution in patients with heart failure or renal failure due to its sodium content, which could exacerbate fluid retention in these patients. These therapies can have a rapid effect; however, they only cause a temporary redistribution of potassium to the intracellular space and do not change total body potassium levels.

Further therapies aimed at increasing potassium elimination from the body include potassium-wasting diuretics, sodium polystyrene sulfonate, and renal replacement therapy. Administration of a loop diuretic enhances renal potassium elimination. Sodium polystyrene sulfonate, a cation-exchange resin, binds potassium in the GI tract and eliminates it from the body. Caution should be used when giving sodium polystyrene sulfonate to patients with heart failure or severe hepatic disease because of the drug's sodium content. Necrosis of the GI tract has been reported in patients who received sodium polystyrene sulfonate in sorbitol. ${ }^{115-120}$ Sorbitol, used as a diluent to counteract constipation with sodium polystyrene sulfonate, is believed to be an important factor in inducing necrosis. ${ }^{15,116}$ As such, sodium polystyrene sulfonate in sorbitol should be used with extreme caution, or 
Table 3.

Treatments for Hyperkalemia ${ }^{19,20,23}$

\begin{tabular}{|c|c|c|c|c|c|}
\hline Treatment & Dose & Route & $\begin{array}{l}\text { Time } \\
\text { to Onset }\end{array}$ & $\begin{array}{l}\text { Duration } \\
\text { of Effect }\end{array}$ & Mechanism of Action and Effects \\
\hline Calcium gluconate $e^{a, b}$ & $\begin{array}{l}1-2 \mathrm{~g}(4.56-9.12 \\
\text { meq cacium })\end{array}$ & I.V. over 5-10 min & $1-2 \mathrm{~min}$ & $10-30 \mathrm{~min}$ & $\begin{array}{l}\text { Antagonizes cardiac conduction } \\
\text { abnormalities }\end{array}$ \\
\hline Sodium bicarbonate ${ }^{a}$ & $50-100$ meq & I.V. over $2-5 \mathrm{~min}$ & $30 \mathrm{~min}$ & $2-6 \mathrm{hr}$ & $\begin{array}{l}\text { Increases serum } \mathrm{pH} \text {; redistributes } \\
\text { potassium into cells }\end{array}$ \\
\hline $\begin{array}{l}\text { Insulin (regular) }{ }^{\mathrm{a}} \text { (with } \\
\text { dextrose) }\end{array}$ & $5-10$ units & $\begin{array}{l}\text { I.V. with } 50 \mathrm{~mL} \text { of } \\
50 \% \text { dextrose } \\
\text { injection }\end{array}$ & $15-45 \min$ & $2-6 \mathrm{hr}$ & Redistributes potassium into cells \\
\hline $50 \%$ dextrose & $50 \mathrm{~mL}(25 \mathrm{~g})$ & I.V. over $5 \mathrm{~min}$ & $30 \mathrm{~min}$ & $2-6 \mathrm{hr}$ & $\begin{array}{l}\text { Increases insulin release; redistributes } \\
\text { potassium into cells; prevents } \\
\text { hypoglycemia when insulin is given }\end{array}$ \\
\hline $10 \%$ dextrose & $1000 \mathrm{~mL}(100 \mathrm{~g})$ & I.V. over 1-2 hr & $30 \mathrm{~min}$ & $2-6 \mathrm{hr}$ & $\begin{array}{l}\text { Increases insulin release; redistributes } \\
\text { potassium into cells; prevents } \\
\text { hypoglycemia when given with } \\
\text { insulin }\end{array}$ \\
\hline Furosemide & $20-40 \mathrm{mg}$ & I.V. & $5-15 \mathrm{~min}$ & $4-6 \mathrm{hr}$ & Increases renal potassium loss \\
\hline $\begin{array}{l}\text { Sodium polystyrene } \\
\text { sulfonate }^{c}\end{array}$ & $15-60 \mathrm{~g}$ & Oral or rectal & $1 \mathrm{hr}$ & $4-6 \mathrm{hr}$ & $\begin{array}{l}\text { Resin exchanges sodium for } \\
\text { potassium; increases fecal potassium } \\
\text { elimination }\end{array}$ \\
\hline Albuterol & $10-20 \mathrm{mg}$ & $\begin{array}{l}\text { Nebulized over } 10 \\
\text { min }\end{array}$ & $30 \mathrm{~min}$ & $1-2 \mathrm{hr}$ & $\begin{array}{l}\text { Stimulates sodium-potassium pump; } \\
\text { redistributes potassium into cells }\end{array}$ \\
\hline Hemodialysis & $2-4 \mathrm{hr}$ & $N A^{d}$ & Immediate & Variable & Removes potassium from plasma \\
\hline
\end{tabular}

${ }^{\text {a}}$ First-line therapies in hyperkalemic emergencies.

${ }^{\mathrm{b}}$ Repeat dose in five minutes if abnormal electrocardiogram persists. Calcium chloride may also be used, but calcium gluconate is preferred over calcium chloride for peripheral venous administration because it causes less venous irritation. Calcium chloride $(1000 \mathrm{mg}=13.6$ meq calcium $)$ provides three times more calcium than calcium gluconate ( $1 \mathrm{~g}=4.56$ meq calcium).

'Can be used to treat acute hyperkalemia, but the effects may not be seen for several hours. Removes $0.5-1$ meq of potassium per $1 \mathrm{~g}$ of sodium polystyrene sulfonate. ${ }^{\mathrm{d}} \mathrm{NA}=$ not applicable.

avoided, especially in uremic patients under stress or with critical illness, ${ }^{115,116,118}$ patients with hypotension or decreased GI perfusion, ${ }^{116,120}$ and patients with GI obstruction or decreased GI motility. ${ }^{119}$ Renal replacement therapy is indicated if hyperkalemia is associated with renal failure or if potassium-wasting diuretics or sodium polystyrene sulfonate fails. ${ }^{18}$ Renal replacement therapy can be used as part of the initial treatment regimen for acute hyperkalemia and will permanently remove potassium from the body, but the effects of potassium removal and lowered serum potassium levels may not be seen for several hours. In addition, renal replacement therapy is more invasive and technically difficult.

Serum potassium should be monitored frequently throughout treatment (every 1-6 hours) in symptomatic patients with severe hyperkalemia, keeping in mind that many therapies for acute hyperkale- mia will only redistribute potassium and not remove it from the body. Continued monitoring of serum potassium levels in patients with hyperkalemia after resolution of symptoms is recommended after therapeutic interventions every 4-12 hours until serum potassium levels return to normal. Routine monitoring of serum potassium levels (every 24-48 hours) is also recommended in adult patients in the ICU.

\section{Phosphorus}

Phosphorus is the main intracellular anion. The normal serum concentration of phosphorus is $2.7-4.5$ $\mathrm{mg} / \mathrm{dL}$; however, the majority of phosphorus in the body exists in the bones and soft tissues, with approximately $1 \%$ of total body phosphorus in the extracellular fluid. . $4,25,27,28$ Therefore, serum phosphorus levels may not reflect total body phosphorus levels. Phosphorus exists primarily as phosphate in the serum and has many important functions, in- cluding bone composition, cell membrane composition, nerve conduction, and muscle function. ${ }^{24,25,27,28}$ It provides energy-rich bonds in the form of adenosine triphosphate (ATP) and is required in all physiological, homeostatic, and metabolic functions that require energy. This is especially important in critically ill patients in the ICU, who often experience hypermetabolism and may have higher phosphorus requirements. Adequate total body phosphorus and phosphate are necessary for glucose utilization, glycolysis, ATP synthesis, numerous biochemical reactions, 2,3-diphosphoglycerate synthesis and function (which are necessary for oxygen release from hemoglobin and delivery to tissues), neurologic function, and muscular function (especially the myocardium and diaphragm). ${ }^{24,25,27,28,121-124}$

Hypophosphatemia. Hypophosphatemia (serum phosphorus concentration of $<2.7 \mathrm{mg} / \mathrm{dL}$ ) can lead to severe clinical sequelae, including 
impaired diaphragmatic contractility and acute respiratory failure, tissue hypoxia, decreased myocardial contractility, paralysis, weakness, paresthesias, neurologic dysfunction, seizures, and death. ${ }^{24,25,27,28,121-128}$ Critically ill adult patients in the ICU often have underlying conditions that predispose them to developing hypophosphatemia (malnutrition, inadequate body phosphorus stores or inadequate phosphate administration, alkalosis [respiratory and metabolic], diabetic ketoacidosis, alcoholism, vomiting or gastric losses) or receive therapies or medications that can cause hypophosphatemia (CRRT, insulin, diuretics, antacids, sucralfate, and administration of carbohydrate loads)..$^{25,27,28}$ Administration of carbohydrate loads or parenteral nutrition is likely to cause hypophosphatemia if an adequate amount of phosphate is not supplied, especially in malnourished patients who are at risk for developing severe hypophosphatemia and refeeding syndrome. ${ }^{30,121,122,125-128}$

Given the potential adverse effects of hypophosphatemia, serum phosphorus concentrations in critically ill patients should be maintained within the normal range. Treatment of hypophosphatemia depends on the magnitude of hypophosphatemia and whether or not the patient is symptomatic. Asymptomatic mild hypophosphatemia may be treated with oral phosphate supplementation if the GI tract is functional. However, oral phosphate supplements may cause diarrhea, and oral absorption may be unreliable. Patients with symptomatic, moderate, or severe hypophosphatemia, along with patients who cannot tolerate oral supplements or receive oral medications, should receive i.v. phosphate supplementation to correct serum phosphorus levels. These conditions can be seen frequently in critically ill patients in the ICU. Estimating the appropriate dosage of phosphate is largely empirical be- cause serum concentrations may not correlate with total body stores. Table 4 provides suggested dosages of i.v. phosphate for hypophosphatemia in patients with normal renal function. ${ }^{129-135}$ In patients with impaired renal function who are not being treated with CRRT, we recommend administering $\leq 50 \%$ of the initial empirical phosphate dosage. Patients being treated with CRRT may require higher initial dosages (i.e., closer to empirical doses used for patients with normal renal function), depending on the severity of hypophosphatemia, the amount of phosphorus being removed with CRRT, and whether or not phosphorus is used in the dialysate or replacement fluid. We recommend using AdjBW in significantly obese patients to minimize the risk of overdosing and subsequent hyperphosphatemia. Further supplementation in all cases should be guided by clinical response to the initial dosage.

The i.v. phosphate preparations used are available as the potassium or sodium salts. Potassium phosphate can be used in patients with simultaneous hypokalemia; otherwise, sodium phosphate is recommended. Clinicians must also be aware of the potassium and sodium content of these preparations. One millimole of potassium phosphate contains 1.47 meq of potassium, and $1 \mathrm{mmol}$ of sodium phosphate contains 1.33 meq of sodium. Total phosphate doses are usually infused over four to six hours to minimize infusionrelated adverse effects (e.g., throm- bophlebitis from potassium phosphate) and to reduce the risk of calcium-phosphate precipitation. However, doses can be infused up to a rate of $7 \mathrm{mmol}$ of phosphate per hour. ${ }^{134,135}$ Phosphorus can quickly shift between compartments within the body and serum concentrations can fluctuate ${ }^{24,28,129}$; therefore, a repeat serum phosphorus level should be checked two to four hours after administering a dose. Additional phosphate supplements should be given until the patient is asymptomatic and the serum phosphorus concentration is at least $>2.0 \mathrm{mg} / \mathrm{dL}$, with a final goal of returning the serum phosphorus levels to within normal range.

Increasing total caloric load has been associated with reduced serum phosphorus levels in patients receiving parenteral nutrition. ${ }^{121}$ It is necessary to provide approximately 10 $15 \mathrm{mmol}$ of phosphate per $1000 \mathrm{kcal}$ to maintain normal serum phosphorus levels. ${ }^{121}$ Severely malnourished patients will likely have higher daily phosphate requirements and should be supplemented accordingly. Critically ill patients may also require additional supplementation or adjustment of parenteral nutrition formulations to meet daily phosphorus requirements.

Patients with refractory hypophosphatemia may require a daily phosphate supplementation of phosphate (1) as an oral powder for solution three or four times daily after meals and at bedtime, (2) as an i.v. supplement, or (3) by increasing the

Table 4.

Empirical Treatment of Hypophosphatemia ${ }^{129-135}$

\begin{tabular}{cc}
\hline $\begin{array}{c}\text { Serum Phosphorus } \\
\text { Concentration }(\mathbf{m g} / \mathrm{dL})\end{array}$ & $\begin{array}{c}\text { I.V. Phosphate } \\
\text { Replacement Dose }(\mathbf{m m o l} / \mathbf{k g})^{\mathbf{a}, \mathbf{b}}\end{array}$ \\
\hline $2.3-2.7$ & $0.08-0.16$ \\
$1.5-2.2$ & $0.16-0.32$ \\
$<1.5$ & $0.32-0.64$ \\
\hline
\end{tabular}

an patients with normal renal function; patients with renal insufficiency should receive $\leq 50 \%$ of the initial empirical dose. Maximum infusion rate $=7 \mathrm{mmol}$ phosphate per hour.

${ }^{b}$ The authors suggest using adjusted body weight (AdjBW) in patients who are significantly obese (weight of $>130 \%$ of ideal body weight [IBW] or have a body mass index of $\left.\geq 30 \mathrm{~kg} / \mathrm{m}^{2}\right)$ : AdjBW $(\mathrm{men})=([\mathrm{wt}(\mathrm{kg})-\mathrm{IBW}(\mathrm{kg})]$ $\times 0.3)+\mathrm{IBW} ; \operatorname{AdjBW}($ women $)=([\mathrm{wt}(\mathrm{kg})-\mathrm{IBW}(\mathrm{kg})] \times 0.25)+\mathrm{IBW}$. 
maintenance amount in parenteral nutrition.

Well-nourished patients receiving nutrition support should have their serum phosphorus levels monitored daily or every other day. Malnourished patients receiving nutrition support should have their levels monitored more closely initially (e.g., every 6-12 hours) as they have a higher risk of developing hypophosphatemia, refeeding syndrome, and subsequent complications. ${ }^{30,122,125-128}$ Patients with renal insufficiency should have their serum phosphorus levels closely monitored because of the risk of hyperphosphatemia.

Hyperphosphatemia. Hyperphosphatemia is defined as a serum phosphorus concentration of $>4.5$ $\mathrm{mg} / \mathrm{dL}$. Serum phosphorus values should be interpreted cautiously since they may not correlate with total body stores of phosphorus. The most common cause of hyperphosphatemia in critically ill patients is renal insufficiency. ${ }^{25,26}$ Excessive i.v. or oral administration of phosphate, such as in ICU patients receiving specialized parenteral or enteral nutrition, can also cause hyperphosphatemia, especially in those with renal insufficiency. ${ }^{25,26,136-138}$ Severe hyperphosphatemia has been reported following treatment of constipation with phosphorus-containing laxatives in patients with compromised renal function. ${ }^{136,138}$ Other etiologies of hyperphosphatemia include acidosis (respiratory and metabolic), hemolysis, rhabdomyolysis, hypoparathyroidism, and vitamin D toxicity. ${ }^{25,26}$

The most common clinical manifestation of hyperphosphatemia is hypocalcemia due to calcium-phosphate precipitation, which can lead to tetany and other clinical manifestations of hypocalcemia. ${ }^{25,26}$ The risk of calciumphosphate precipitation appears to increase when the serum calcium level multiplied by the serum phosphorus concentration exceeds 55-60 $\mathrm{mg}^{2} / \mathrm{dL}^{2} .{ }^{98,139,140}$ Calcium-phosphate crystals can also deposit into soft tissues and cause further organ damage. ${ }^{25,26,140,141}$

Treatment of hyperphosphatemia requires identification and correction of the underlying cause. The goals of therapy include returning the serum phosphorus concentration to normal $(2.7-4.5 \mathrm{mg} / \mathrm{dL})$, avoiding or resolving symptoms of hyperphosphatemia, and maintaining the serum (calcium $\times$ phosphorus) at $<55-60 \mathrm{mg}^{2} / \mathrm{dL}^{2} .{ }^{140,141}$ Daily phosphate intake (e.g., in parenteral or enteral nutrition formulas) must be adjusted for patients with renal insufficiency. Requirements may differ in patients receiving CRRT or intermittent hemodialysis because of the variation in the amount of phosphorus removed during these therapies. Oral phosphate binders, available as calcium, aluminum, and magnesium salts or as the nonionic phosphate binder sevelamer, can be effective in lowering serum phosphorus levels. Table 5 lists suggested pharmacologic treatments of hyperphosphatemia. ${ }^{142-144}$

Phosphate binders, especially those containing magnesium and aluminum, should be used cautiously. Magnesium may cause diarrhea and aluminum may cause constipation. Both magnesium and aluminum may accumulate in patients with renal insufficiency and lead to toxicity. Therefore, calcium salts are preferred in patients with chronic renal insufficiency or when long-term therapy is required. Because it is significantly more expensive than other treatments, sevelamer should be reserved for use in hyperphosphatemia with hypercalcemia in chronic renal failure or hyperphosphatemia refractory to other treatments. Prolonged use of phosphate binders may paradoxically result in hypophosphatemia.

Because of the delayed onset of therapies for hyperphosphatemia, frequent monitoring of serum phosphorus levels is not usually needed. Routine monitoring of serum phosphorus levels (every 24-48 hours) is probably

Table 5.

Pharmacologic Treatment of Hyperphosphatemia ${ }^{142-144}$

\begin{tabular}{|c|c|c|c|}
\hline Medication & $\begin{array}{l}\text { Dosage } \\
\text { Forms }\end{array}$ & $\begin{array}{c}\text { Initial } \\
\text { Recommended Dosage }^{a}\end{array}$ & $\begin{array}{c}\text { Maximum } \\
\text { Recommended Dosage }^{a}\end{array}$ \\
\hline Calcium acetate & $\begin{array}{l}\text { Tablet: } 667 \mathrm{mg} \\
\text { Gelcap: } 667 \mathrm{mg}\end{array}$ & $\begin{array}{l}2 \text { tablets or gelcaps three times } \\
\text { daily with meals }\end{array}$ & $\begin{array}{l}4 \text { tablets or gelcaps with each meal } \\
\text { daily; avoid hypercalcemia }\end{array}$ \\
\hline Calcium carbonate & $\begin{array}{l}\text { Tablet, capsule, liquid, and } \\
\text { powder; various strengths }\end{array}$ & $1-2 \mathrm{~g}$ three times daily with meals & 7 g/day; avoid hypercalcemia \\
\hline Aluminum hydroxide & $\begin{array}{l}\text { Tablets: } 300 \text { and } 600 \mathrm{mg} \\
\text { Suspension: } 320 \mathrm{mg} / 5 \mathrm{~mL}\end{array}$ & $\begin{array}{l}1-2 \text { tablets or } 15-30 \mathrm{~mL} \text { three or } \\
\text { four times daily with meals and at } \\
\text { bedtime }\end{array}$ & $\begin{array}{l}1800 \mathrm{mg} \text { (3-6 tablets) or } 30 \mathrm{~mL} \text { every } \\
4 \mathrm{hr}\end{array}$ \\
\hline Magnesium hydroxide & $\begin{array}{l}\text { Tablets: } 300 \text { and } 600 \mathrm{mg} \\
\text { Liquids: } 400 \text { and } 800 \mathrm{mg} / \\
5 \mathrm{~mL}\end{array}$ & $\begin{array}{l}1-2 \text { tablets or } 5-15 \mathrm{~mL} \text { three times } \\
\text { daily with meals }\end{array}$ & $\begin{array}{l}\text { 2-4 tablets four times daily with meals } \\
\text { or } 15 \mathrm{~mL} \text { four times daily with meals } \\
\text { and at bedtime }\end{array}$ \\
\hline Sevelamer & $\begin{array}{l}\text { Tablets: } 400 \text { and } 800 \mathrm{mg} \\
\text { Capsule: } 403 \mathrm{mg}\end{array}$ & $\begin{array}{l}800-1600 \mathrm{mg} \text { three times daily } \\
\text { with meals }\end{array}$ & $4000 \mathrm{mg}$ three times daily with meals \\
\hline
\end{tabular}

${ }^{a}$ May require higher doses in rare situations or in some patients with chronic renal insufficiency and severe hyperphosphatemia. The dosage should be adjusted to achieve the goal serum phosphorus level in these situations. 
appropriate for most patients; patients with severe symptoms or those receiving renal replacement therapy may require more frequent monitoring.

\section{Calcium}

Calcium functions in bone metabolism, blood coagulation, platelet adhesion, neuromuscular activity, endocrine and exocrine secretory functions, and electrophysiology of the heart and smooth muscles. Serum calcium concentration is regulated by parathyroid hormone, vitamin $\mathrm{D}$, and calcitonin. ${ }^{32}$ The normal range for total serum calcium concentration is $8.6-10.2 \mathrm{mg} / \mathrm{dL}$.

About $99 \%$ of total body calcium is found in bones, with less than $1 \%$ in the serum..$^{33}$ Approximately 40 $50 \%$ of calcium in the blood is bound to plasma proteins, primarily albumin. ${ }^{33,35}$ Hypoalbuminemia, which is frequently seen in critically ill patients, can therefore cause a decrease in total serum calcium levels. For each $1-\mathrm{g} / \mathrm{dL}$ decrease in serum albumin concentration (below $4 \mathrm{~g} / \mathrm{dL}$ ), total serum calcium concentration decreases by approximately $0.8 \mathrm{mg} / \mathrm{dL} \cdot{ }^{34}$ Therefore, in patients with hypoalbuminemia the serum calcium concentration should be corrected for this. The corrected serum calcium concentration in patients with hypoalbuminemia can be estimated using the following equation:

Corrected serum calcium conc. $=$ serum calcium conc. $+(0.8 \times[4-$ serum albumin conc.])

Ionized or unbound calcium is the biologically active form of calcium and accounts for about $50 \%$ of calcium in the blood under normal conditions. ${ }^{33}$ Ionized serum calcium is closely regulated by the endocrine system and is a better indicator of the functional status of calcium metabolism than total calcium levels. Because of the poor correlation between ionized calcium and total calcium levels, especially in ICU pa- tients with hypoalbuminemia or acid-base imbalance, ${ }^{145}$ direct measurement of ionized calcium concentration in critically ill ICU patients is recommended. ${ }^{32-35}$ The normal range for ionized serum calcium concentration is $1.12-1.30 \mathrm{mmol} / \mathrm{L}$. Metabolic alkalosis increases calcium binding to plasma proteins, reducing the serum level of ionized calcium. Conversely, metabolic acidosis decreases calcium binding to plasma proteins, increasing the serum concentration of ionized calcium.

Hypocalcemia. Hypocalcemia (total serum calcium concentration of $<8.6 \mathrm{mg} / \mathrm{dL}$ or ionized calcium concentration of $<1.1 \mathrm{mmol} / \mathrm{L}$ ) is primarily due to hypoalbuminemia. Other causes include hypomagnesemia, hyperphosphatemia, sepsis, pancreatitis, renal insufficiency, hypoparathyroidism, and administration of blood preserved with citrate. ${ }^{33,35}$ The hallmark sign of severe acute hypocalcemia is tetany. Other neuromuscular, CNS, and cardiovascular symptoms may be present, even with mild to moderate hypocalcemia. Signs and symptoms of chronic hypocalcemia include skin manifestations, such as brittle and grooved nails, hair loss, dermatitis, and eczema. ${ }^{32}$

I.V. calcium gluconate and calcium chloride are used to treat hypocalcemia when rapid correction of serum calcium levels is required. Calcium chloride provides three times more elemental calcium than an equivalent amount of calcium gluconate. Recent reports have described errors in calcium dosing and administration due to confusion over the calcium salt, dosage, and manner in which calcium was ordered, as well as potentially confusing product labels. ${ }^{146-149} \mathrm{We}$ recommend that institutions establish a standardized method for ordering calcium to minimize the risk of dosing errors. ${ }^{150-152}$ Calcium gluconate should be used as the preferred salt for routine calcium maintenance and supplementation; calcium chlo- ride should be restricted to use in urgent and emergent situations. One method to reduce the risk for errors associated with ordering and dosing of calcium is to order calcium gluconate in milliequivalents of calcium or in grams of calcium gluconate and to order calcium chloride in milliequivalents of calcium or in milligrams of calcium chloride. Regardless of the method used to order calcium salts, the terms "ampule," "amp," and " $m L$ " should not be used to order the dosage of calcium, and the calcium salt should always be specified. ${ }^{150}$ Calcium gluconate is also the preferred salt for peripheral venous administration since calcium chloride infusion may cause tissue necrosis if extravasation occurs. ${ }^{153,154}$ Calcium should not be infused in the same i.v. catheter as solutions containing phosphate because of the risk of calciumphosphate precipitation.

Asymptomatic hypocalcemia due to hypoalbuminemia requires no therapy. Severe hypocalcemia (total serum calcium concentration of $<7.5$ $\mathrm{mg} / \mathrm{dL}$ or ionized calcium concentration of $<0.9 \mathrm{mmol} / \mathrm{L}$ ) or acute symptomatic hypocalcemia requires prompt correction with i.v. calcium

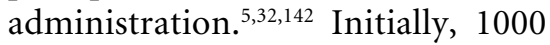
$\mathrm{mg}$ of calcium chloride (13.6 meq of calcium) or $3 \mathrm{~g}$ of calcium gluconate (13.7 meq of calcium) may be given over 10 minutes to control symptoms (Table 6). Since an i.v. bolus dose of calcium may only be effective for about two hours or less, ${ }^{35,155,156}$ severe acute hypocalcemia may not be corrected with intermittent i.v. bolus doses. Instead, a continuous infusion of i.v. calcium may be required, with close monitoring of serum calcium levels at least every six hours during the infusion., ${ }^{5,32}$ The infusion rate should not exceed $0.8-1.5$ $\mathrm{meq} / \mathrm{min}$ because of the potential risk for cardiac arrhythmias associated with rapid calcium infusion. ${ }^{5}$

Typically, a calcium gluconate dose of 1-2 g (4.56-9.12 meq of calcium) is mixed in $100 \mathrm{~mL}$ of $5 \%$ dex- 
Table 6.

Empirical Dosages of I.V. Calcium $5,32,142$

\begin{tabular}{|c|c|c|c|}
\hline Degree of Hypocalcemia & $\begin{array}{c}\text { Preferred } \\
\text { Calcium Salt }^{\mathrm{a}}\end{array}$ & $\begin{array}{l}\text { Intermittent } \\
\text { Bolus Dosage }\end{array}$ & Continuous Infusion Dosage $^{b}$ \\
\hline $\begin{array}{l}\text { Mild to moderate, } \\
\text { asymptomatic }\end{array}$ & Gluconate & $\begin{array}{l}\text { 1-2 g calcium gluconate over } \\
30-60 \text { minutes; may repeat } \\
\text { every } 6 \text { hours as needed }\end{array}$ & $\begin{array}{l}4.56-9.12 \text { meq calcium over } 30- \\
60 \text { minutes; may repeat every } 6 \\
\text { hours as needed }\end{array}$ \\
\hline Severe, symptomatic & Chloride or gluconate & $\begin{array}{l}1000 \text { mg calcium chloride or } 3 \\
\text { g calcium gluconate over } 10 \\
\text { minutes; may repeat as } \\
\text { needed }\end{array}$ & $\begin{array}{l}13.6 \text { meq calcium over } 10 \\
\text { minutes; may repeat as needed }\end{array}$ \\
\hline $\begin{array}{l}\text { Severe, symptomatic; } \\
\text { refractory to intermittent } \\
\text { bolus doses }\end{array}$ & Chloride or gluconate & Not applicable & $\begin{array}{l}0.8-1.5 \text { meq calcium per minute; } \\
\text { monitor serum calcium every } 6 \\
\text { hours or more frequently }\end{array}$ \\
\hline
\end{tabular}

${ }^{\mathrm{a} C a l c i u m}$ chloride should be administered via a central venous catheter to avoid extravasation and tissue necrosis; $1000 \mathrm{mg}$ calcium chloride = 13.6 meq calcium; $1 \mathrm{~g}$ calcium gluconate $=4.56$ meq calcium .

${ }^{\mathrm{b}}$ Maximum rate of intravenous infusion $=1.5$ meq calcium per minute.

trose injection or $0.9 \%$ sodium chloride injection and infused over 30-60 minutes. The dose can be repeated every 6 hours as needed until serum calcium levels have normalized. Hypocalcemia due to citrated blood transfusion can be treated by administering 1.35 meq of calcium for each $100 \mathrm{~mL}$ of blood transfused. ${ }^{142}$ In addition to the monitoring described above, routine monitoring of serum calcium levels (total or ionized) in adult patients in the ICU is recommended (every 24-48 hours).

If concomitant hypomagnesemia is present, magnesium supplements should be given to help correct the hypocalcemia. The exact mechanism of this interaction is unknown; however, it is hypothesized that magnesium deficiency may impair the release or activity of parathyroid hormone. ${ }^{26,157,158}$

Oral calcium supplements may be used once serum calcium levels are corrected by administration of i.v. calcium. Chronic or asymptomatic hypocalcemia can be treated with oral calcium supplements and vitamin D. Table 7 describes the calcium supplements available, their elemental calcium content, and the forms available for specific administration routes.

Hypercalcemia. Hypercalcemia is defined as a total serum calcium concentration of $>10.2 \mathrm{mg} / \mathrm{dL}$ and can be characterized as mild to moderate (total serum calcium concentration of $10.3-12.9 \mathrm{mg} / \mathrm{dL}$ ) or severe (total serum calcium concentration of $\geq 13$ $\mathrm{mg} / \mathrm{dL}$ ).

The primary causes of hypercalcemia are malignancy (e.g., breast cancer, lung cancer, multiple myeloma, non-Hodgkin's lymphoma) and primary hyperparathyroidism..$^{33,36}$ Certain medications (e.g., thiazide diuretics, lithium), vitamin A toxicity, vitamin D toxicity, milk-alkali syndrome, adrenal insufficiency, immobilization, Paget's disease, rhabdomyolysis, and tuberculosis can also cause hypercalcemia..$^{5,33,36,37}$ Chronic hypercalcemia may cause nephrolithiasis, metastatic calcification, and renal failure. ${ }^{37}$

Mild hypercalcemia usually responds well to hydration and ambulation. Patients with severe hypercalcemia frequently suffer from anorexia, fatigue, or confusion. Severe hypercalcemia may have cardiac manifestations, such as bradycardia or arrhythmias with ECG changes. ${ }^{31}$ Severe hypercalcemia or hypercalcemic crisis with a total serum calcium concentration of $>13 \mathrm{mg} / \mathrm{dL}$ requires emergency treatment because it can lead to acute renal failure, obtundation, ventricular arrhythmias, coma, and death..$^{33,36}$ Treatment should begin promptly, starting with i.v. hydration using $0.9 \%$ sodium chloride infusion at $200-300 \mathrm{~mL} / \mathrm{hr}$ to reverse the intravascular volume contraction caused by hypercalcemia. After adequate hydration is achieved, furosemide $40-100 \mathrm{mg}$ i.v. every one to four hours can be used to enhance renal calcium elimination and avoid fluid overload from the saline hydration, but caution should be taken to avoid further intravascular volume depletion. Saline hydration and furosemide can reduce serum calcium levels by about $2-3 \mathrm{mg} / \mathrm{dL}$ within the first 48 hours of treatment. ${ }^{159} \mathrm{Hemo}-$ dialysis may be necessary in lifethreatening hypercalcemia or in patients with impaired renal function. ${ }^{38}$

Bisphosphonates (e.g., etidronate, pamidronate, zoledronic acid) are potent inhibitors of bone resorption via action on osteoblast and osteoclast precursors and are frequently used for the treatment of hypercalcemia of malignancy. Etidronate disodium is effective when given intravenously at a dosage of $7.5 \mathrm{mg} / \mathrm{kg} /$ day over 2 hours for three to seven days. Pamidronate disodium is given as a single i.v. dose of 60-90 mg infused over 2-24 hours. The usual dose of zoledronic acid is a single i.v. dose of 4-8 mg infused over 15 minutes. Because of their prolonged time until onset of action, bisphosphonates have a limited role in the acute treatment of hypercalcemia; serum calcium levels usually begins to decline within two days of the first bisphos- 
Table 7.

\section{Calcium Supplements}

\begin{tabular}{lccc}
$\begin{array}{c}\text { Calcium } \\
\text { Salt }\end{array}$ & $\begin{array}{c}\text { Elemental } \\
\text { Calcium }(\mathbf{m e q} / \mathbf{g})\end{array}$ & $\begin{array}{c}\text { Elemental } \\
\text { Calcium }(\%)\end{array}$ & $\begin{array}{c}\text { Administration } \\
\text { Route }^{\mathrm{a}}\end{array}$ \\
\hline Calcium chloride & 13.6 & 27 & I.V. \\
Calcium gluconate & 4.56 & 9 & I.V. or oral \\
Calcium acetate & 12.7 & 25 & I.V. or oral \\
Calcium carbonate & 20 & 40 & Oral \\
Calcium citrate & 10.5 & 21 & Oral \\
\hline
\end{tabular}

${ }^{\mathrm{a}}$ Maximum rate of i.v. infusion $=1.5 \mathrm{meq} / \mathrm{min}$.

phonate dose. A major advantage of pamidronate and zoledronic acid is their effectiveness in a single-dose regimen. ${ }^{160}$ Zoledronic acid also has the advantage of a short infusion time.

Bisphosphonates remain the drugs of choice for the treatment of hypercalcemia outside of the acute setting. However, other medications, including glucocorticoids, calcitonin, plicamycin, and gallium nitrate, have also been used. ${ }^{33,36,38,159}$ I.V. phosphates should not be used to correct hypercalcemia because of the potential for calcium-phosphate precipitation, which could result in further morbidity, including metastatic calcification, hypotension, and renal failure.

\section{Magnesium}

Magnesium is the second most abundant intracellular cation. It is found primarily in bone, muscle, and soft tissue, with about $1 \%$ of the total body content in the extracellular fluid. ${ }^{26,44}$ The normal serum magnesium concentration ranges from 1.5 to 2.4 $\mathrm{mg} / \mathrm{dL}$. Magnesium serves as an important cofactor for numerous enzymes and in many biochemical reactions and is a required cofactor for reactions involving ATP. ${ }^{39,40}$ Magnesium is absorbed throughout the small intestine, with the majority of absorption occurring in the ileum and jejunum..$^{41}$ Magnesium homeostasis is primarily handled by the kidneys, ${ }^{42}$ but GI function, parathyroid hormone, and plasma magnesium concentrations also play a major role. ${ }^{41}$ Several other factors can affect magnesium homeostasis, including the patient's clinical condition, medications (e.g., loop diuretics, amphotericin $\mathrm{B}$ ), and alcohol use.

Hypomagnesemia. Hypomagnesemia (serum magnesium concentration of $<1.5 \mathrm{mg} / \mathrm{dL}$ ) is frequently observed in critically ill patients $\mathrm{s}^{42,161-163}$ and has been associated with increased mortality. ${ }^{163,164}$ Severe hypomagnesemia (serum magnesium concentration of $<1.0 \mathrm{mg} / \mathrm{dL}$ ) can result in ECG changes, arrhythmias (including torsades de pointes), seizures, coma, and even death. ${ }^{43,44}$ Hypomagnesemia may cause concomitant refractory hypokalemia and hypocalcemia. Although the exact mechanisms of these observations are unknown, hypokalemia is likely a result of impaired activity of the sodiumpotassium pump, ${ }^{113}$ and hypocalcemia is likely due to impaired parathyroid release or activity. ${ }^{26,157,158}$

Causes of hypomagnesemia include excessive GI losses, renal losses, surgery, trauma, infection or sepsis, burns, transfusion of blood preserved with citrate, starvation, malnutrition, alcoholism, and certain medications (e.g., thiazide and loop diuretics, aminoglycosides, amphotericin B, cisplatin, cyclosporine). ${ }^{43,44,46,165,166}$ Use of cardiac glycosides (e.g., digoxin) has also been associated with hypomagnesemia, possibly by enhancing magnesium excretion, and hypomagnesemia may potentiate digoxin toxicity (e.g., dysrhythmias). ${ }^{43,44,46,165,166}$

Only about $1 \%$ of magnesium stores are found in the extracellular space, and serum magnesium levels may not correlate with intracellular concentrations or total body magnesium levels. ${ }^{44,104,166}$ Therefore, treatment of hypomagnesemia is largely empirical. Monitoring serum magnesium levels and monitoring the patient for resolution of signs and symptoms of hypomagnesemia are the most readily available method for assessing the effectiveness of magnesium supplementation. Because hypomagnesemia is observed frequently in critically ill patients ${ }^{42,161-163}$ and has been associated with increased mortality, ${ }^{163,164}$ the serum magnesium concentrations in critically ill patients in the ICU should be kept at $1.5 \mathrm{mg} / \mathrm{dL}$ or higher. Patients who have recently had an acute myocardial infarction may require higher concentrations $(\geq 1.7 \mathrm{mg} / \mathrm{dL})$ to prevent cardiac arrhythmias. ${ }^{167,168}$

The goals of therapy should be to avoid or resolve symptoms, return the serum magnesium concentration to $1.5-2.4 \mathrm{mg} / \mathrm{dL}$, and avoid hypermagnesemia. Oral magnesium supplements are available; however, problems with administration, slow onset of action, and GI intolerance may limit their utility. The i.v. route of administration is preferred, especially in critically ill patients with severe symptomatic hypomagnesemia. Few i.v. dosing regimens for the treatment and repletion of hypomagnesemia have been suggested. ${ }^{46,166-172}$ Magnesium deficiency has been associated with a total body magnesium deficiency of 1.0-2.0 meq/kg. ${ }^{169}$ Magnesium distributes into tissues slowly, but renal elimination is rapid, with up to $50 \%$ of an i.v. dose of magnesium excreted in the urine. ${ }^{42-45,169,170,173}$ Therefore, infusion time is critical, and additional supplementation may be required after the initial dose, with total repletion taking several days. For patients with mild to moderate hypomagnesemia, 8-32 meq of magnesium should be given (up to $1.0 \mathrm{meq} / \mathrm{kg}$ ). Severe hypomagnesemia should be treated with 32-64 meq of magne- 
sium (up to $1.5 \mathrm{meq} / \mathrm{kg}$ ) (Table 8 ). Doses of $<6 \mathrm{~g}$ of magnesium sulfate should be infused over 8-12 hours, with higher doses infused over 24 hours. Because of the slow equilibration of magnesium between serum and intracellular spaces and tissues (e.g., bone, red blood cells, muscle), ${ }^{44,174}$ the serum magnesium levels could appear artificially high if measured too soon after a dose is given. ${ }^{174}$

We recommend administering $50 \%$ or less of the suggested empirical magnesium dose in patients with renal insufficiency to decrease the risk of hypermagnesemia. For i.v. administration, the magnesium sulfate concentration should be diluted to $20 \%(20 \mathrm{~g} / 100 \mathrm{~mL})$ or less before administration, but the undiluted $50 \%$ solution may be administered intramuscularly to adults. ${ }^{175}$ Because a renal threshold for magnesium exists, with up to $50 \%$ of an i.v. dose being eliminated in the urine, ${ }^{42-45,169,170,173}$ i.v. magnesium sulfate should be administered at a maximum rate of $1 \mathrm{~g} / \mathrm{hr}$ (8 meq of magnesium per hour) in asymptomatic patients with hypomagnesemia, and the total dose should not exceed $12 \mathrm{~g}$ (100 meq of magnesium) over 12 hours. ${ }^{169}$ Careful monitoring is also prudent, especially when doses approach the maximum recommendations. ${ }^{169}$ Rapid rates of magnesium infusion may exceed the renal threshold, resulting in increased urinary magnesium excre-

Table 8.

\section{Empirical Treatment of Hypomagnesemia 42,45,166-173}

\begin{tabular}{lcc}
\hline \multicolumn{1}{c}{ Severity } & $\begin{array}{c}\text { Serum Magnesium } \\
\text { Concentration }(\mathrm{mg} / \mathrm{dL})\end{array}$ & $\begin{array}{c}\text { I.V. Magnesium } \\
\text { Replacement Dose,b }^{\mathrm{a}, \mathrm{b}}\end{array}$ \\
\hline Mild to moderate & $1.0-1.5$ & $8-32$ meq magnesium (1-4 g \\
& & magnesium sulfate), up to \\
& & $1.0 \mathrm{meq} / \mathrm{kg}$ \\
Severe & $<1.0$ & $32-64$ meq magnesium (4-8 \\
& g magnesium sulfate), up \\
& to 1.5 meq $/ \mathrm{kg}$ \\
\hline
\end{tabular}

an patients with normal renal function; patients with renal insufficiency should receive $\leq 50 \%$ of the initial empirical dose. Maximum rate of infusion $=8$ meq magnesium per hour ( $1 \mathrm{~g}$ magnesium sulfate per hour), up to 100 meq magnesium (approximately $12 \mathrm{~g}$ magnesium sulfate) over 12 hours if asymptomatic; up to 32 meq magnesium (4 g magnesium sulfate) over 4-5 minutes in severe symptomatic hypomagnesemia. $1 \mathrm{~g}$ magnesium sulfate $=8.1$ meq magnesium.

${ }^{b}$ The authors suggest using adjusted body weight (AdjBW) in patients who are significantly obese (weight of $>130 \%$ of ideal body weight [IBW] or have a body mass index of $\left.\geq 30 \mathrm{~kg} / \mathrm{m}^{2}\right)$ : AdjBW $(\mathrm{men})=([\mathrm{wt}(\mathrm{kg})-\mathrm{IBW}(\mathrm{kg})]$ $\times 0.3)+\mathrm{IBW} ; \operatorname{AdjBW}($ women $)=([\mathrm{wt}(\mathrm{kg})-\mathrm{IBW}(\mathrm{kg})] \times 0.25)+\mathrm{IBW}$. causes of hypermagnesemia are renal insufficiency and iatrogenic causes..$^{39,44}$

The primary therapy for hypermagnesemia is to discontinue exogenous magnesium administration. I.V. calcium should be administered to patients with severe symptomatic hypermagnesemia to reverse the cardiovascular and neuromuscular effects. ${ }^{44,47}$ I.V. calcium chloride doses of $500-1000 \mathrm{mg}(7.8-13.6 \mathrm{meq}$ of calcium) should be administered via a central venous catheter over 5-10 minutes and repeated until symptoms resolve. If the patient does not have a central venous catheter, $1-3 \mathrm{~g}$ of i.v. calcium gluconate (4.56-13.7 meq of calcium) should be infused over 3-10 minutes. Patients with asymptomatic hypermagnesemia may be treated with magnesium restriction, loop diuretics, or hemodialysis. ${ }^{44,47}$ Magnesium-containing antacids and other medications containing magnesium should be avoided in patients with renal insufficiency. Serum magnesium levels should be monitored at least once daily during treatment. More frequent monitoring may be required in symptomatic patients when more aggressive therapy is used (e.g., loop diuretics, hemodialysis). Serum magnesium concentration should be maintained in the normal range $(1.5-2.4 \mathrm{mg} / \mathrm{dL})$ and hypomagnesemia avoided during treatment.

\section{Conclusion}

Treatment of electrolyte disorders is often empirical, based on published literature, expert opinion and recommendations, and the patient's response to the initial treatment. Clinicians should be knowledgeable about electrolyte homeostasis and the underlying pathophysiology of electrolyte disorders to provide optimal therapy for patients.

\section{References}

1. Rose BD, Post TW. Clinical physiology of acid-base and electrolyte disorders. 5 th ed. New York: McGraw-Hill; 2001:241-98,682-821. 
2. McManus ML, Churchwell KB, Strange $K$. Regulation of cell volume in health and disease. N Engl J Med. 1995; 333: 1260-6.

3. Berl T, Anderson RJ, McDonald KM et al. Clinical disorders of water metabolism. Kidney Int. 1976; 10:117-32.

4. Fitzsimons JT. The physiological basis of thirst. Kidney Int. 1976; 10:3-11.

5. Joy MS, Hladik GA. Disorders of sodium, water, calcium, and phosphorus homeostasis. In: Dipiro JT, Talbert RL, Yee GC et al., eds. Pharmacotherapy: a pathophysiologic approach. 5th ed. New York: McGraw-Hill; 2002:953-79.

6. Kumar S, Berl T. Sodium. Lancet. 1998; 352:220-8.

7. Friedler RM, Koffler A, Kurokawa K. Hyponatremia and hypernatremia. Clin Nephrol. 1977; 7:163-72.

8. Fried LF, Palevsky PM. Hyponatremia and hypernatremia. Med Clin North Am. 1997; 81:585-609.

9. Androgue HJ, Madias NE. Hyponatremia. N Engl J Med. 2000; 342:1581-9.

10. Cadnapaphornchai MA, Schrier RW. Pathogenesis and management of hyponatremia. Am J Med. 2000; 109:68892.

11. Sterns RH. The management of hyponatremic emergencies. Crit Care Clin. 1991; 7:127-42.

12. Arieff AI, Guisado R. Effects on the central nervous system of hypernatremic and hyponatremic states. Kidney Int. 1976; 10:104-16.

13. Terpstra TL, Terpstra TL. Syndrome of inappropriate antidiuretic hormone secretion: recognition and management. Medsurg Nurs. 2000; 9:61-70.

14. Androgue HJ, Madias NE. Hypernatremia. N Engl J Med. 2000; 342:1493-9.

15. Ober KP. Diabetes insipidus. Crit Care Clin. 1991; 7:109-25.

16. Bendz H, Aurell M. Drug-induced diabetes insipidus: incidence, prevention and management. Drug Saf. 1999; 21: 449-56.

17. Halperin ML, Kamel KS. Potassium Lancet. 1998; 352:135-40.

18. Brophy DF, Gehr TW. Disorders of potassium and magnesium homeostasis. In: Dipiro JT, Talbert RL, Yee GC et al., eds. Pharmacotherapy: a pathophysiologic approach. 5th ed. New York: McGraw-Hill; 2002:981-93.

19. Kunau RT, Stein JH. Disorders of hypoand hyperkalemia. Clin Nephrol. 1977; 7:173-90.

20. Mandal AK. Hypokalemia and hyperkalemia. Med Clin North Am. 1997; 81:611-39.

21. Gennari FJ. Hypokalemia. N Engl J Med. 1998; 339:451-8.

22. Freedman BI, Burkart JM. Hypokalemia. Crit Care Clin. 1991; 7:143-53.

23. Williams ME. Hyperkalemia. Crit Care Clin. 1991; 7:155-74.

24. Lau K. Phosphate disorders. In: Kokko JP, Tannen RL, eds. Fluids and electrolytes. Philadelphia: W.B. Saunders; 1986:398-471.
25. Peppers MP, Geheb M, Desai T. Hypophosphatemia and hyperphosphatemia. Crit Care Clin. 1991; 7:201-14.

26. Weisinger JR, Bellorin-Font E. Magnesium and phosphorous. Lancet. 1998; 352:391-6.

27. Knochel JP. The pathophysiology and clinical characteristics of severe hypophosphatemia. Arch Intern Med. 1977; 137:203-20.

28. Stoff JS. Phosphate homeostasis and hypophosphatemia. Am J Med. 1982; 72: 489-95.

29. Ritz E. Acute hypophosphatemia. Kidney Int. 1982; 22:84-94.

30. Brooks MJ, Melnik G. The refeeding syndrome: an approach to understanding its complications and preventing its occurrence. Pharmacotherapy. 1995; 15: 713-26.

31. Agus ZS, Wasserstein A, Goldfarb S. Disorders of calcium and magnesium homeostasis. Am J Med. 1982; 72:473-88.

32. Olinger ML. Disorders of calcium and magnesium metabolism. Emerg Med Clin North Am. 1989; 7:795-822.

33. Bushinsky DA, Monk RD. Calcium. Lancet. 1998; 352:306-11.

34. Singer FR, Bethune JE, Massry SG. Hypercalcemia and hypocalcemia. Clin Nephrol. 1977; 7:154-62.

35. Zaloga GP. Hypocalcemic crisis. Crit Care Clin. 1991; 7:191-200.

36. Davis KD, Attie MF. Management of severe hypercalcemia. Crit Care Clin. 1991; 7:175-90.

37. Mundy GR, Guise TA. Hypercalcemia of malignancy. Am J Med. 1997; 103:13445.

38. Deftos LJ. Hypercalcemia: mechanisms, differential diagnosis, and remedies. Postgrad Med. 1996; 100:119-26.

39. Wacker WE, Parisi AF. Magnesium metabolism. N Engl J Med. 1968; 278:65863,712-7,772-6.

40. Wacker WE. The biochemistry of magnesium. Ann N Y Acad Sci. 1969; 162: 717-26.

41. MacIntyre I, Robinson CJ. Magnesium and the gut: experimental and clinical observations. Ann N Y Acad Sci. 1969; 162:865-73.

42. Heaton FW. The kidney and magnesium homeostasis. Ann N Y Acad Sci. 1969; 162:775-85.

43. Graber TW, Yee AS, Baker FJ. Magnesium: physiology, clinical disorders, and therapy. Ann Emerg Med. 1981; 10:49-57.

44. Reinhart RA. Magnesium metabolism: a review with special reference to the relationship between intracellular content and serum levels. Arch Intern Med. 1988; 148:2415-20

45. Martin HE. Clinical magnesium deficiency. Ann N Y Acad Sci. 1969; 162:891900.

46. Salem M, Munoz R, Chernow B. Hypomagnesemia in critical illness: a common and clinically important problem. Crit Care Clin. 1991; 7:225-52.

47. Van Hook JW. Hypermagnesemia. Crit Care Clin. 1991; 7:215-23.
48. Hankin ME, Munz K, Steinbeck AW. Total body water content in normal and grossly obese women. Med J Aust. 1976; 2:533-7.

49. Watson PE, Watson ID, Batt RD. Total body water volumes for adult males and females estimated from simple anthropometric measurements. Am J Clin Nutr. 1980; 33:27-39.

50. Schoeller DA, van Santen E, Peterson DW et al. Total body water measurement in humans with ${ }^{18} \mathrm{O}$ and ${ }^{2} \mathrm{H}$ labeled water. Am J Clin Nutr. 1980; 33:2686-93.

51. Webster JD, Hesp R, Garrow JS. The composition of excess weight in obese women estimated by body density, total body water and total body potassium. Hum Nutr Clin Nutr. 1984; 38: 299-306.

52. Foster GD, Wadden TA, Mullen JL et al. Resting energy expenditure, body composition, and excess weight in the obese. Metabolism. 1988; 37:467-72.

53. Norenberg MD, Leslie KO, Robertson AS. Association between rise in serum sodium and central pontine myelinolysis. Ann Neurol. 1982; 11:128-35.

54. Sterns RH, Riggs JE, Schochet SS. Osmotic demyelination syndrome following correction of hyponatremia. $N$ Engl J Med. 1986; 314:1535-42.

55. Sterns RH. Severe symptomatic hyponatremia: treatment and outcome. A study of 64 cases. Ann Intern Med. 1987; 107:656-64.

56. Ayus JC, Krothapalli RK, Arieff AI. Treatment of symptomatic hyponatremia and its relation to brain damage. $N$ Engl J Med. 1987; 317:1190-5.

57. Laureno R, Karp BI. Pontine and extrapontine myelinolysis following rapid correction of hyponatraemia. Lancet. $1988 ; 1: 1439-41$.

58. Cluitmans FH, Meinders AE. Management of severe hyponatremia: rapid or slow correction? Am J Med. 1990; 88: 161-6.

59. Sterns RH. The treatment of hyponatremia: first, do no harm. Am J Med. 1990; 88:557-60.

60. Cheng JC, Zikos D, Skopicki HA et al. Long-term neurologic outcome in psychogenic water drinkers with severe symptomatic hyponatremia: the effect of rapid correction. Am J Med. 1990; 88: 561-6.

61. Sterns RH. Severe hyponatremia: the case for conservative management. Crit Care Med. 1992; 20:534-9.

62. Karp BI, Laureno R. Pontine and extrapontine myelinolysis: a neurologic disorder following rapid correction of hyponatremia. Medicine. 1993; 72:35973.

63. Sterns RH, Cappuccio JD, Silver SM et al. Neurologic sequelae after treatment of severe hyponatremia: a multicenter perspective. J Am Soc Nephrol. 1994; 4: 1522-30.

64. Ellis SJ. Severe hyponatremia: complications and treatment. QJM. 1995; 88:905-9. 
65. Oh MS, Kim HJ, Carroll HJ. Recommendations for treatment of symptomatic hyponatremia. Nephron. 1995; 70:143-50.

66. Pham PC, Chen PV, Pham PT. Overcorrection of hyponatremia: where do we go wrong? Am J Kidney Dis. 2000; 36: E12.

67. Arieff AI, Llach F, Massry SG. Neurological manifestations and morbidity of hyponatremia: correlation with brain water and electrolytes. Medicine. 1976; 55:121-9.

68. Anderson RJ, Chung HM, Kluge R et al. Hyponatremia: a prospective analysis of its epidemiology and the pathogenic role of vasopressin. Ann Intern Med. 1985; 102:164-8.

69. Androgue HJ, Madias NE. Aiding fluid prescription for the dysnatremias. Intensive Care Med. 1997; 23:309-16.

70. Hantman D, Rossier B, Zohlman R et al. Rapid correction of hyponatremia in the syndrome of inappropriate secretion of antidiuretic hormone. Ann Intern Med. 1973; 78:870-5.

71. Ayus JC, Olivero JJ, Frommer JP. Rapid correction of severe hyponatremia with intravenous hypertonic saline solution. Am J Med. 1982; 72:43-8.

72. Ayus JC, Krothapalli RK, Arieff AI Changing concepts of treatment of severe symptomatic hyponatremia. Rapid correction and possible relation to central pontine myelinolysis. Am J Med. 1985; 78:897-902.

73. Berl T. Treating hyponatremia: damned if we do and damned if we don't. Kidney Int. 1990; 37:1006-18.

74. Kinzie BJ. Management of the syndrome of inappropriate secretion of antidiuretic hormone. Clin Pharm. 1987; 6:625-33.

75. Decaux G, Waterlot $Y$, Genette F et al Treatment of the syndrome of inappropriate secretion of antidiuretic hormone. N Engl J Med. 1981; 304:329-30.

76. Decaux G, Waterlot Y, Genette F et al. Inappropriate secretion of antidiuretic hormone treated with frusemide. $\mathrm{Br}$ Med J Clin Res Ed. 1982; 285:89-90.

77. Decaux G. Long-term treatment of patients with inappropriate secretion of antidiuretic hormone by the vasopressin receptor antagonist conivaptan, urea, or furosemide. Am J Med. 2001; 110:582-4.

78. Miyagawa CI. The pharmacologic management of the syndrome of inappropriate secretion of antidiuretic hormone. Drug Intell Clin Pharm. 1986; 20:527-31.

79. Decaux G, Brimioulle S, Genette F et al. Treatment of the syndrome of inappropriate secretion of antidiuretic hormone by urea. Am J Med. 1980; 69:99-106.

80. Decaux G, Genette F. Urea for long-term treatment of syndrome of inappropriate secretion of antidiuretic hormone. $\mathrm{Br}$ Med J Clin Res Ed. 1981; 283:1081-3.

81. Decaux G, Prospert F, Penninckx R et al. Five-year treatment of the chronic syndrome of inappropriate secretion of ADH with oral urea. Nephron. 1993; 63:468-70.
82. De Troyer A, Demanet JC. Correction of antidiuresis by demeclocycline. $N$ Engl $J$ Med. 1975; 293:915-8.

83. Cherrill DA, Stote RM, Birge JR et al. Demeclocycline treatment in the syndrome of inappropriate antidiuretic hormone secretion. Ann Intern Med. 1975; 83:654-6.

84. Forrest JN, Cox M, Hong C et al. Superiority of demeclocycline over lithium in the treatment of chronic syndrome of inappropriate secretion of antidiuretic hormone. N Engl J Med. 1978; 298:173-7.

85. Perks WH, Walters EH, Tams IP et al. Demeclocycline in the treatment of the syndrome of inappropriate secretion of antidiuretic hormone. Thorax. 1979; 34:324-7.

86. Danovitch GM, Le Roith D, Glick S. Renal function during treatment of inappropriate secretion of antidiuretic hormone with demeclocycline. Isr J Med Sci. 1978; 14:852-7.

87. Carrilho F, Bosch J, Arroyo V et al. Renal failure associated with demeclocycline in cirrhosis. Ann Intern Med. 1977; 87:1957.

88. Miller PD, Linas SL, Schrier RW. Plasma demeclocycline levels and nephrotoxicity. Correlation in hyponatremic cirrhotic patients. JAMA. 1980; 243:2513-5.

89. Zegers de Beyl D, Naeije R, de Troyer A. Demeclocycline treatment of water retention in congestive heart failure. $\mathrm{Br}$ Med J. 1978; 1:760.

90. Braden GL, Geheb MA, Shook A et al. Demeclocycline-induced natriuresis and renal insufficiency: in vivo and in vitro studies. Am J Kidney Dis. 1985; 5: 270-7.

91. Tanay A, Yust I, Peresecenschi G et al. Long-term treatment of the syndrome of inappropriate antidiuretic hormone secretion with phenytoin. Ann Intern Med. 1979; 90:50-2.

92. White MG, Fetner CD. Treatment of the syndrome of inappropriate secretion of antidiuretic hormone with lithium carbonate. N Engl J Med. 1975; 292: 390-2.

93. Katz MA. Hyperglycemia-induced hyponatremia-calculation of expected serum sodium depression. $\mathrm{N} \mathrm{Engl} \mathrm{J} \mathrm{Med.}$ 1973; 289:843-4

94. Snyder NA, Feigal DW, Arieff A. Hypernatremia in elderly patients. A heterogeneous, morbid, and iatrogenic entity. Ann Intern Med. 1987; 107:309-19.

95. Palevsky PM, Bhagrath R, Greenberg A. Hypernatremia in hospitalized patients. Ann Intern Med. 1996; 124:197-203.

96. Mandal AK, Saklayen MG, Hillman NM et al. Predictive factors for high mortality in hypernatremic patients. Am J Emerg Med. 1997; 15:130-2.

97. Brennan S, Ayus JC. Acute versus chronic hypernatremia: how fast to correct ECF volume? J Crit Illn. 1990; 5:330-3.

98. Kahn A, Brachet E, Blum D. Controlled fall in natremia and risk of seizures in hypertonic dehydration. Intensive Care Med. 1979; 5:27-31.
99. Stone KA. Lithium-induced nephrogenic diabetes insipidus. J Am Board Fam Pract. 1999; 12:43-7.

100. Drug-induced diabetes insipidus: has its importance been diluted? Drug Ther Perspect. 2001; 17:10-2.

101. Constandis DD, Schriever HG. Severe lithium-induced diabetes insipidus in a surgical patient treated with hydrochlorothiazide. Am J Surg. 1981; 141:741-3.

102. Allen HM, Jackson RL, Winchester MD et al. Indomethacin in the treatment of lithium-induced nephrogenic diabetes insipidus. Arch Intern Med. 1989; 149: 1123-6.

103. Battle DC, von Riotte AB, Gaviria $M$ et al. Amelioration of polyuria by amiloride in patients receiving longterm lithium therapy. $N$ Engl J Med. 1985; 312:408-14.

104. Dyckner T, Wester PO. The relation between extra- and intracellular electrolytes in patients with hypokalemia and/or diuretic treatment. Acta Med Scand. 1978; 204:269-82.

105. Kruse JA, Carlson RW. Rapid correction of hypokalemia using concentrated intravenous potassium chloride infusions. Arch Intern Med. 1990; 150:613-7.

106. Kruse JA, Clark VL, Carlson RW et al. Concentrated potassium chloride infusions in critically ill patients with hypokalemia. J Clin Pharmacol. 1994; 34: 1077-82.

107. Hamill RJ, Robinson LM, Wexler HR et al. Efficacy and safety of potassium infusion therapy in hypokalemic critically ill patients. Crit Care Med. 1991; 9:6949.

108. Agarwal A, Wingo CS. Treatment of hypokalemia. N Engl J Med. 1999; 340:1545.

109. Strom BL, Carson JL, Schinnar R et al. Upper gastrointestinal tract bleeding from oral potassium chloride. Comparative risk from microencapsulated vs. wax-matrix formulations. Arch Intern Med. 1987; 147:954-7.

110. Sinar DR, Bozymski EM, Blackshear JL. Effects of oral potassium supplements on upper gastrointestinal mucosa: multicenter clinical comparison of three formulations and placebo. Clin Ther. 1986; 8:157-63.

111. McMahon FG, Ryan JR, Akdamar K et al. Upper gastrointestinal lesions after potassium chloride supplements: a controlled clinical trial. Lancet. 1982; 2: 1059-61.

112. Cohn JN, Kowey PR, Whelton PK et al. New guidelines for potassium replacement in clinical practice. Arch Intern Med. 2000; 160:2429-36.

113. Skou JC. Further investigations on a $\mathrm{Mg}^{++}+\mathrm{Na}^{+}$-activated adenosinetriphosphate, possibly related to the active, linked transport of $\mathrm{Na}^{+}$and $\mathrm{K}^{+}$across the nerve membrane. Biochim Biophys Acta. 1960; 42:6-23.

114. Ryan MP. Interrelationships of magnesium and potassium homeostasis. Miner Electrolyte Metab. 1993; 19:290-5. 
115. Lillemoe KD, Romolo JL, Hamilton SR et al. Intestinal necrosis due to sodium polystyrene (Kayexalate) in sorbitol enemas: clinical and experimental support for the hypothesis. Surgery. 1987; 101: 267-72.

116. Rashid A, Hamilton SR. Necrosis of the gastrointestinal tract in uremic patients as a result of sodium polystyrene sulfonate (Kayexalate) in sorbitol: an underrecognized condition. Am J Surg Pathol. 1997; 21:60-9.

117. Roy-Chaudhury P, Meisels IS, Freedman $S$ et al. Combined gastric and ileocecal toxicity (serpiginous ulcers) after oral Kayexalate in sorbitol therapy. Am J Kidney Dis. 1997; 30:120-2.

118. Rogers FB, Li SC. Acute colonic necrosis associated with sodium polystyrene sulfonate (Kayexalate) enemas in a critically ill patient: case report and review of the literature. J Trauma. 2001; 51: 395-7.

119. Abraham SC, Bhagavan BS, Lee LA et al. Upper gastrointestinal tract injury in patients receiving Kayexalate (sodium polystyrene sulfonate) in sorbitol. Am J Surg Pathol. 2001; 25:637-44.

120. Cheng ES, Stringer KM, Pegg SP. Colonic necrosis and perforation following oral sodium polystyrene sulfonate (Resonium A/Kayexalate) in a burn patient. Burns. 2002; 28:189-90.

121. Sheldon GF, Grzyb S. Phosphate depletion and repletion: relation to parenteral nutrition and oxygen transport. Ann Surg. 1975; 182:683-9.

122. Travis SF, Sugerman HJ, Ruberg RL et al. Alterations of red-cell glycolytic intermediates and oxygen transport as a consequence of hypophosphatemia in patients receiving intravenous hyperalimentation. N Engl J Med. 1971; 283:7638.

123. Newman JH, Neff TA, Ziporin P. Acute respiratory failure associated with hypophosphatemia. N Engl J Med. 1977; 296: 1101-3.

124. Aubier M, Murciano D, Lecocguic Y et al. Effect of hypophosphatemia on diaphragmatic contractility in patients with acute respiratory failure. $N$ Engl J Med. 1985; 313:420-4

125. Silvis SE, Paragas PD. Paresthesias, weakness, seizures, and hypophosphatemia in patients receiving hyperalimentation. Gastroenterology. 1972; 62: 513-20.

126. Sand DW, Pastore RA. Paresthesias and hypophosphatemia occurring with parenteral alimentation. Am J Dig Dis. 1973; 18:709-13.

127. Weinsier RL, Krumdieck CL. Death resulting from overzealous total parenteral nutrition: the refeeding syndrome revisited. Am J Clin Nutr. 1981; 34:393-9.

128. Youssef HA. Hypophosphatemic respiratory failure complicating total parenteral nutrition-an iatrogenic potentially lethal hazard. Anesthesiology. 1982; 57:246. Letter.
129. Lentz RD, Brown DM, Kjellstrand CM. Treatment of severe hypophosphatemia. Ann Intern Med. 1978; 89:941-4.

130. Vannatta JB, Whang R, Papper S. Efficacy of intravenous phosphorous therapy in the severely hypophosphatemic patient. Arch Intern Med. 1981; 141: 885-7.

131. Andress DL, Vannatta JB, Whang R. Treatment of refractory hypophosphatemia. South Med J. 1982; 75:7667.

132. Vannatta JB, Andress DL, Whang R et al. High-dose intravenous phosphorus therapy for severe complicated hypophosphatemia. South Med J. 1983; 76: 1424-6.

133. Kingston M, Al-Siba'i MB. Treatment of severe hypophosphatemia. Crit Care Med. 1985; 13:16-8.

134. Rosen GH, Boullata JI, O’Rangers EA et al. Intravenous phosphate repletion regimen for critically ill patients with moderate hypophosphatemia. Crit Care Med. 1995; 23:1204-10.

135. Clark CL, Sacks GS, Dickerson RN et al. Treatment of hypophosphatemia in patients receiving specialized nutrition support using a graduated dosing scheme: results from a prospective clinical trial. Crit Care Med. 1995; 23:1504-10.

136. Escalante CP, Weiser MA, Finkel K. Hyperphosphatemia associated with phosphorus-containing laxatives in a patient with chronic renal insufficiency. South Med J. 1997; 90:240-2.

137. Ehrenpreis ED, Wieland JM, Cabral J et al. Symptomatic hypocalcemia, hypomagnesemia, and hyperphosphatemia secondary to Fleet's Phospho-Soda colonoscopy preparation in a patient with a jejunoileal bypass. Dig Dis Sci. 1997; 42:858-60.

138. Ullah N, Yeh R, Ehrinpreis M. Fatal hyperphosphatemia from a phosphosoda bowel preparation. J Clin Gastroenterol. 2002; 34:457-8.

139. Velentzas C, Meindok H, Oreopoulos DG et al. Visceral calcification and the CaXP product. Adv Exp Med Biol. 1978; 103:195-201.

140. Block GA, Port FK. Re-evaluation of risks associated with hyperphosphatemia and hyperparathyroidism in dialysis patients: recommendations for a change in management. Am J Kidney Dis. 2000; 35:1226-37.

141. Goodman WG, Goldin J, Kuizon BD et al. Coronary-artery calcification in young adults with end-stage renal disease who are undergoing dialysis. $N$ Engl J Med. 2000; 342:1478-83.

142. Lacy CH, Armstrong LL, Goldman MP et al., eds. Drug information handbook. 13th ed. Hudson, OH: Lexi-Comp Inc.; 2005:77-8,239-42,924-5,1362.

143. PhosLo (calcium acetate) package insert. Braintree, MA: Braintree Laboratories, Inc.; 2001 Nov.

144. Renagel (sevelamer hydrochloride) package insert. Cambridge: Genzyme Corporation; 2000 Jul.
145. Drop LJ, Laver MB. Low plasma ionized calcium and response to calcium therapy in critically ill man. Anesthesiology. 1975; 43:300-6.

146. Smetzer J, Cohen MR, eds. Safety briefs. ISMP medication safety alert! Vol. 2. Huntingdon Valley, PA; 1997 Oct 22:1.

147. Smetzer J, Cohen MR, eds. Placing limits on drug inventory minimizes errors with automated dispensing equipment. ISMP medication safety alert! Vol. 3. Huntingdon Valley, PA; 1998 Dec 2:1.

148. Smetzer J, Cohen MR, eds. Art imitates life! Error portrayal really happened. ISMP medication safety alert! Vol. 5. Huntingdon Valley, PA; 2000 Dec 13:1.

149. Smetzer J, Cohen MR, eds. Remote order entry: innovative practice to reduce distractions and offer 24-hour pharmacy service. ISMP medication safety alert! Vol. 7. Huntingdon Valley, PA; 2002 Apr 17:2.

150. Smetzer J, Cohen MR, eds. Which i.v. calcium: chloride or gluconate? ISMP medication safety alert! Vol. 2. Huntingdon Valley, PA; 1997 May 7:1.

151. Smetzer J, Cohen MR, eds. Safety briefs. ISMP medication safety alert! Vol. 6. Huntingdon Valley, PA; 2001 Jan 10:2.

152. Smetzer J, Cohen MR, eds. ISMP Quarterly Action Agenda: OctoberDecember 2000. ISMP medication safety alert! Vol. 6. Huntingdon Valley, PA; 2001 Jan 24:2-3.

153. Jucgla A, Sais G, Curco N et al. Calcinosis cutis following liver transplantation: a complication of intravenous calcium administration. Br J Dermatol. 1995; 132:275-8

154. Semple P, Booth C. Calcium chloride; a reminder. Anaesthesia. 1996; 51:93. Letter.

155. Carlon GC, Howland WS, Kahn RC et al. Calcium chloride administration in normocalcemic critically ill patients. Crit Care Med. 1980; 8:209-12.

156. Vincent JL, Bredas P, Jankowski S et al. Correction of hypocalcaemia in the critically ill: what is the haemodynamic benefit? Intensive Care Med. 1995; 21:838-41.

157. Anast CS, Winnacker JL, Forte LR et al. Impaired release of parathyroid hormone in magnesium deficiency. $\mathrm{J}$ Clin Endocrinol Metab. 1976; 42:707-17.

158. Fatemi G, Ryzen E, Flores J et al. Effect of experimental human magnesium depletion on parathyroid hormone secretion and 1,25-dihydroxyvitamin D metabolism. J Clin Endocrinol Metab. 1991; 73: 1067-72.

159. Chisholm MA, Mulloy AL, Taylor AT. Acute management of cancer-related hypercalcemia. Ann Pharmacother. 1996; 30:507-13.

160. Davidson TG. Conventional treatment of hypercalcemia of malignancy. Am J Health-Syst Pharm. 2001; 58(suppl 3): S8-15.

161. Ryzen E, Wagers PW, Singer FR et al. Magnesium deficiency in a medical ICU population. Crit Care Med. 1985; 13:1921. 
162. Reinhart RA, Desbiens NA. Hypomagnesemia in patients entering the ICU. Crit Care Med. 1985; 13:506-7.

163. Chernow B, Bamberger S, Stoiko M et al. Hypomagnesemia in patients in postoperative intensive care. Chest. 1989; 95: 391-7.

164. Rubeiz GJ, Thill-Baharozian M, Hardie $\mathrm{D}$ et al. Association of hypomagnesemia and mortality in acutely ill medical patients. Crit Care Med. 1993; 21:203-9.

165. Frankel H, Haskell R, Lee SY et al. Hypomagnesemia in trauma patients. World $J$ Surg. 1999; 23:966-9.

166. Dickerson RN, Brown RO. Hypomagnesemia in hospitalized patients receiving nutritional support. Heart Lung. 1985 ; 14:561-9.

167. Rasmussen HS, McNair P, Norregard $\mathrm{P}$ et al. Intravenous magnesium in acute myocardial infarction. Lancet. 1986; 1: 234-6.

168. Ceremuzynski L, Van Hao N. Ventricular arrhythmias late after myocardial infarction are related to hypomagnesemia and magnesium loss: preliminary trial of corrective therapy. Clin Cardiol. 1993; 16:493-6.

169. Flink EB. Therapy of magnesium deficiency. Ann N Y Acad Sci. 1969; 162:9015.

170. Oster JR, Epstein M. Management of magnesium depletion. Am J Nephrol. 1988; 8:349-54.

171. Sacks GS, Brown RO, Dickerson RN et al. Mononuclear blood cell magnesium content and serum magnesium concentration in critically ill hypomagnesemic patients after replacement therapy. $\mathrm{Nu}$ trition. 1997; 13:303-7.

172. Huycke MM, Naguib MT, Stroemmel MM et al. A double-blind placebocontrolled crossover trial of intravenous magnesium sulfate for foscarnetinduced ionized hypocalcemia and hypomagnesemia in patients with AIDS and cytomegalovirus infection. Antimicrob Agents Chemother. 2000; 44:2143-8.

173. Hebert P, Mehta N, Wang J et al. Functional magnesium deficiency in critically ill patients identified using a magnesium-loading test. Crit Care Med. 1997; 25:749-55.

174. Barnes BA. Magnesium conservation: a study of surgical patients. Ann N Y Acad Sci. 1969; 162:786-801.

175. Trissel LA. Handbook on injectable drugs. 12th ed. Bethesda, MD: American Society of Health-System Pharmacists 2003:868-74.

176. Mordes JP, Swartz R, Arky RA. Extreme hypermagnesemia as a cause of refractory hypotension. Ann Intern Med. 1975; 83:657-8. 